\title{
A novel leaf-rolling chironomid, Eukiefferiella endobryonia sp. nov. (Diptera, Chironomidae, Orthocladiinae), highlights the diversity of underwater chironomid tube structures
}

\author{
Yume Imada \\ I Graduate School of Science and Engineering, Ehime University, 2-5 Bunkyo-cho, Matsuyama, Ehime 790- \\ 8577, Japan
}

Corresponding author: Yume Imada (imayume.ac@gmail.com)

Academic editor: F. L. da Silva | Received 4 November 2019 | Accepted 17 December 2019 | Published 22 January 2020

http://zoobank.org/A511F89A-4BBB-408B-A77B-D8CD694AD519

Citation: Imada Y (2020) A novel leaf-rolling chironomid, Eukiefferiella endobryonia sp. nov. (Diptera, Chironomidae, Orthocladiinae), highlights the diversity of underwater chironomid tube structures. ZooKeys 906: 73-111. https://doi. org/10.3897/zookeys.906.47834

\begin{abstract}
The non-biting midges, Chironomidae (Diptera), are dominant components of most freshwater ecosystems. Many chironomids construct tubes or cases as larvae out of various materials bound together with silk. The structures of tubes show a wide range of variation, and some are morphologically comparable to those of caddisflies. Herein a new species is described, Eukiefferiella endobryonia sp. nov., which exhibits a very unusual behavior in which it constructs tubes from aquatic mosses. This species' fourth-instar larvae construct their cases exclusively from the leaves of Fontinalis mosses (Hypnales: Fontinalaceae) and exhibit a stereotyped behavior in which they remain attached to the apical shoot of the moss stem. The larvae then pupate within the case. The case of E. endobryonia sp. nov. represents one of only a few examples of chironomid tubes made exclusively out of plants. Based on the species delimitation analyses using the partial COI sequences, together with some morphological and behavioral characteristics, this species is hypothesized to be a member of devonica group, and especially may have a close affinity to E. dittmari (Lehman). A provisional typology for the diversity of chironomid tube structures is provided, with a summary of different tube structures, which can be used for future research.
\end{abstract}

\section{Keywords}

bryophytivore; freshwater; Orthocladiinae; tubicolous; Eukiefferiella

Copyright Yume Imada. This is an open access article distributed under the terms of the Creative Commons Attribution License (CC BY 4.0), which permits unrestricted use, distribution, and reproduction in any medium, provided the original author and source are credited. 


\section{Introduction}

Many aquatic animals build biogenic structures, such as burrows, tubes, and cases (Chamberlain 1975). Construction behavior has evolved in a taxonomically diverse array of animals, including Protozoa, Mollusca, Annelida, Polychaeta, Crustacea, Echinodermata, fishes, and Nematoda (Nehring et al. 1990; Dudgeon 1994; Charbonneau and Hare 1998; Nehring 1993; Merz 2015). Dwelling tubes can be preserved as ichnofossils and provide evidence for activities by organisms over geological time (Chamberlain 1975; Gall 1983; Minter et al. 2016). In the freshwater realm, three insect orders contain notable numbers of species with such tube construction behaviors (Wallace and Merritt 1980): Trichoptera, Diptera (family Chironomidae), and Ephemeroptera (family Polymitarcyidae). Tube morphology and ultrastructure vary significantly among taxa, and these tubes may serve various functions (Dudgeon 1994).

Chironomidae is a diverse nematocerous family of Diptera, to which ca. 7290 described species belong (Pape et al. 2011; Courtney et al. 2017). Larval chironomids inhabit a broad spectrum of habitats, especially in permanent and temporal freshwater environments ranging from running and standing water, to madicolous zones, temporary pools, and phytotelmata; a substantial number of species also occur in terrestrial habitats (Oliver 1971; Pinder 1995). Their modes of feeding are also diverse (Thienemann 1954). They have been classified as belonging to most functional feeding groups (Cummins 1974), including collector-gatherers, collector-filterers, scrapers, shredders, engulfers, and piercers (predators and parasites) (Berg 1995).

Most larvae of Chironomidae construct dwelling tubes or cases by combining various particles together with silk (Oliver 1971) that they secrete from their labial gland (Sehnal and Sutherland 2008). In many cases, chironomid tubes are soft, flexible, and cryptic in sediments (Heckman 2018). Several functions have been hypothesized for the tubicolous habit of these species, including improved respiration (Walshe 1950; Kon and Hidaka 1983; Stief et al. 2005), feeding (Walshe 1947, 1951), anti-predator defense (Hershey 1987), and protection against physiological stress (e.g., toxicity and desiccation) (Hinton 1951; Kikawada et al. 2005; Vedamanikam and Shazili 2009). Tube-making chironomids can be important ecosystem engineers (Lawton and Jones 1995). Tubedwelling chironomids can be pioneer species, as they often colonize newly submerged substrata first and in greater numbers than other colonists (Nilsen and Larimore 1973). Tube-dwelling, deposit-feeding chironomids play important roles in the bioturbation of organic detritus (Dudgeon 1994; Svensson and Leonardson 1996; Chapin 2011). Consequently, they impact the physical properties of sediments and drive biogeochemical processes in lake ecosystems (Ólafsson and Paterson 2004; Hölker et al. 2015). The presence and feeding activities of chironomids also have impacts on the structures of meiofaunal and protozoan communities (Ptatscheck et al. 2017; Webert et al. 2017). Additionally, tube structures, by themselves, can exert considerable effects on the periphytic diatom flora living on river rocks (Pringle 1985; Hershey et al. 1988; Herren et al. 2017).

In lotic habitats, aquatic mosses harbor various benthic invertebrates (Suren 1993). In many stream habitats, Chironomidae can be abundant on clumps of aquatic 
fountain mosses, Fontinalis spp. (Linhart et al. 2002; Vlčková et al. 2002; Bogut et al. 2009). Aquatic bryophytes can interact with aquatic arthropods by providing them with space and shelter from predators (Stream Bryophyte Group 1999). However, it is unclear whether aquatic bryophytes are an important food source for invertebrates (Winterbourn et al. 1986; McWilliam-Hughes et al. 2009), or not (Bunn et al. 1989; Suren and Winterbourn 1991). The inhibition of invertebrate feeding on bryophytes is often explained as likely resulting from the low nutritional value and presence of secondary chemicals in aquatic mosses (Parker et al. 2007).

While searching for arthropods that interact with aquatic bryophytes in North America, I discovered chironomid larvae that were notably distinct from other tubicolous chironomids due to their unique tube-constructing behavior. Specifically, the fourth-instar larvae of these chironomids make cases exclusively using the leaves of Fontinalis mosses. Although a number of chironomid larvae were found attached to moss shoots, some larvae could be clearly distinguished by their construction behavior at the shoot tips of Fontinalis mosses. This species turned out to be a new species belonging to the genus Eukiefferiella Thienemann (Orthocladiinae). The life history of this species was clarified with the aid of DNA barcoding, and a description of it is given herein, including an account of its larval tube construction behavior. As the taxonomy of Eukiefferiella can be problematic, the genetic differentiation of the new species in comparison to some congeners which are hypothetically closely related is estimated using methods for delimitation of species. Additionally, a provisional typology of chironomid tube morphology is provided, to highlight the diverse morphology of tube structure among chironomids.

\section{Materials and methods}

\section{Study sites}

Chironomids were collected during 24-27 February and on 10 November in 2018 in a stream connected to Mountain Lake, Virginia, USA. Mountain Lake is an oligotrophic lake that is located at an elevation of $1181 \mathrm{~m}$ above sea level near the summit of Salt Pond Mountain, and is the only natural lake of substantial size in the unglaciated part of the Southern Appalachian Mountain Range (Sharp 1933). Mountain Lake possesses an unusually high diversity of aquatic plants and invertebrates (reviewed by Parker 2003). Two species of Fontinalis have been recorded from the lake itself and the brooks in its vicinity, F. dalecarlica B. S. G. and F. novae-angliae Sull. (Studler 1982). $F$. dalecarlica is common in gently flowing water bodies, including in the brook that I sampled. Additional samples were collected during 4-9 April and 11-13 November in 2018 in a flowing-water stream, Rowans River, along Sparks Lane in Cades Cove, in the northwest part of the Great Smoky Mountains National Park (GRSM), Tennessee, USA, ca. $430 \mathrm{~km}$ away from Mountain Lake. Fontinalis novae-angliae with rigid stems and concave leaves occur from the streambed. Samples were collected in GRSM under research permit GRSM-2017-SCI-2389. 


\section{Collections, rearing, and observations}

Insects were searched for underwater in the sampled streams and brooks and were collected together with the host plants occurring in their habitats. At Mountain Lake Biological Station, the clumps of mosses were detangled from detritus, and sediments were washed out of them. The larvae were placed in small plastic cases and observed with a microscope. The plastic chambers were constantly cooled with a refrigerant to keep their temperature in the range between $10-22{ }^{\circ} \mathrm{C}$. Fourth-instar larvae were observed for $27 \mathrm{~h}$ in total, between 08:00 hrs and 18:00 hrs during 4-25 March 2018. Rearing and observations of chironomid larvae were performed at the National Museum of Natural History, Smithsonian Institution.

\section{Molecular analyses}

To compare and differentiate the chironomids of different stages and sexes occurring at the study sites, their partial COI (cytochrome c oxidase subunit I) gene sequences were determined. Total genomic DNA was extracted from 23 specimens at different stages, including adults (from a single adult leg or abdomen), larvae (two or three abdominal segments), and pupae (the whole abdomen) or pupal exuviae, using a NucleoSpin Tissue kit (Macherey-Nagel, Düren, Germany) and following the protocol provided by the manufacturer, with some modifications. The protocol was modified as follows: (i) tissue was digested for $48 \mathrm{~h}$ at $58{ }^{\circ} \mathrm{C}$; (ii) after digestion with proteinase $\mathrm{K}$, tissues were removed, washed in distilled water and used for morphological assessments; and (iii) the final elution volume was $30 \mu \mathrm{L}$. The primer pair used for the COI region consisted of primers 911 and 912 of Folmer et al. (1994), as used in some previous DNA barcoding and phylogenetic studies of Chironomidae (e.g., Guryev et al. 2001; Stur and Ekrem 2011; Cranston et al. 2012). Amplifications of the COI region were performed in a thermocycler, with an initial denaturation step of $94^{\circ} \mathrm{C}$ for $4 \mathrm{~min}$, followed by 40 cycles of $94^{\circ} \mathrm{C}$ for $45 \mathrm{~s}, 55^{\circ} \mathrm{C}$ for $45 \mathrm{~s}$, and $72{ }^{\circ} \mathrm{C}$ for $1 \mathrm{~min}$, and one cycle at $72^{\circ} \mathrm{C}$ for $10 \mathrm{~min}$. Amplification products were purified with ExoSAP-IT, according to the manufacturer's instructions.

Direct sequencing of polymerase chain reaction (PCR) products was performed using the ABI Big Dye Terminator 3.1 cycle sequencing kit (Applied Biosystems, Lennik, Belgium) while following the manufacturer's instructions and was carried out in an ABI 3130 Capillary Electrophoresis Genetic analyzer. Both DNA strands were sequenced. Sequences were deposited in the GenBank database (Table 1).

\section{Phylogenetic analyses}

Sequence trace files were edited with 4Peaks v. 1.8 (by A. Griekspoor and Tom Groothuis, nucleobytes.com). Nucleotide sequences were aligned with CLustal W implemented in MEGA 7 (Kumar et al. 2016). To evaluate if the new species is phyloge- 
netically exclusive among hypothetically closely related species (particularly the species in 'devonica' group, as discussed later) and to assess the intra- and interspecific genetic distances, the species delimitation plug-in in the software Geneious Prime 2019.2.3 (www.geneious.com) was used (Masters et al. 2011; Kearse et al. 2012).

The COI sequences of a rich record of Eukiefferiella species were found in GenBank with 1052 fragment sequences (accessed on October 10 ${ }^{\text {th }}, 2019$ ), although the sequence data identified at the species level were available only for five species (i.e., E. devonica (Edw.), E. ilkleyensis (Edw.), E. claripennis (Lundbeck), E. minor (Edw.), E. dittmari (Lehman)). In the dataset, 23 sequence data representing five species were included (Table 1), as well as five sequences obtained in this study. Phylogenetic trees were inferred by Bayesian inference (BI). Trees were rooted with two species of the genus Cardiocladius (i.e., C. capucinus (Zetterstedt), C. fuscus Kieff.). Evolutionary model was selected with MrModeltest v. 4.0b10 (Nylander 2004). The best fitting models were chosen with the Akaike Information Criterion (Akaike 1973). For the COI dataset, GTR + Gamma model was selected and used for the following Bayesian phylogenetic analysis. BI trees were constructed with MrBAYES v.3.2.6 (Huelsenbeck and Ronquist 2001), using the plug-in of Geneious Prime, based on a cold chain and four heated chains with $\mathrm{T}=0.2$, running for 1,100,000 generations with a sample frequency of 200 . The first 100,000 trees were discarded and the remaining trees were used to build a consensus tree, with estimated Bayesian posterior probabilities (PP). At the point of burn-in, the chains had all converged to a stable standard deviation of split frequencies lower than 0.01 .

The species delimitation plug-in in the Geneious Prime 2019.2.3 (Kearse et al. 2012; Masters et al. 2011) was used (1) to measure the phylogenetic support of new species described herein, and (2) to evaluate the genetic differentiation among and within species, among other congeners which are hypothetically closely related to this species. For these purposes, Rosenberg's $P_{A B}$ (Rosenberg 2007) Rodrigo's P (Randomly Distinct) (Rodrigo et al. 2008) were calculated. Rosenberg's $\mathrm{P}_{\mathrm{AB}}$ is a test for taxonomic distinctiveness of a clade based on the null hypothesis that monophyly is a chance outcome of random branching. Rodrigo's P(Randomly Distinct) ('Rodrigo's P (RD)') is the probability that a focal clade has the observed degree of distinctiveness (i.e., the ratio between the distance from a species-defining node to the tips of the tree, and the distance from that same node to its immediate ancestor) due to random coalescent processes (Rodrigo et al. 2008). Focal groups with values between 0.05 and 1 represent groups that have branching events that would be expected under the coalescent model in a Wright-Fishe population and a strict molecular clock. Additionally, six statistics which are useful to species delimitation were presented, along with Rosenberg's $\mathrm{P}_{\mathrm{AB}}$ and Rodrigo's P (RD): the average pairwise tree distance, among members of the focal species/populations ('D Intra') and between the members of the focal species and members of the next closest species ('D Inter'); as a measure of genetic differences between the focal species and its closest neighboring species, the ratio of D Intra to D Inter ('Intra/Inter'); as the measures for evaluating diagnosability of each species/population, the mean probability of making a correct identification of a hypothetical sample of the focal species using placement on a tree under two different criteria, 'P ID(Strict)' (the sample 


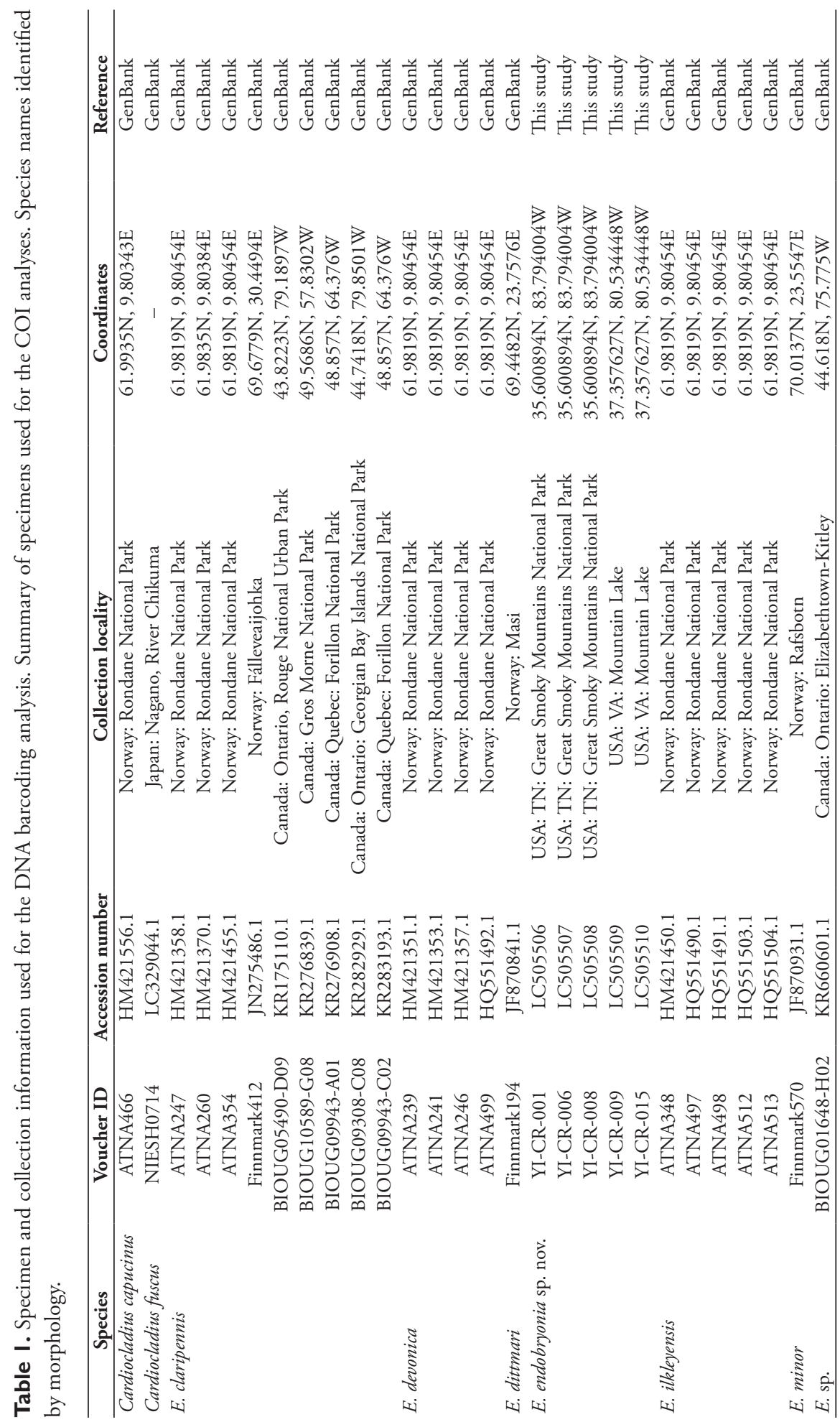


must fall within the species clade) and 'P ID(Liberal)' (the sample is allowed to fall sister to or within a species clade); the mean distance between the most recent common ancestor of a species and its members ('Av(MRCA)'). Accession number, voucher ID, and information on the localities for each specimen are shown in Table 1.

\section{Morphological analyses}

All specimens of adult abdomens, pupae, and larvae were digested with proteinase $\mathrm{K}$, which made it relatively easy to examine the specimens morphologically. When necessary, the apical portion of the adult abdomen was macerated with warm $\left(\mathrm{ca} .90{ }^{\circ} \mathrm{C}\right.$ ) $5 \% \mathrm{KOH}$ and rinsed with distilled water. Each body part sample was mounted on a microscopic slide with Euparal.

The terminology of morphological features used herein followed Sæther (1971, $1977,1980)$. The antennal ratio (AR), leg ratios (LR, BV, SV), wing ratio (L/WR) and hypopygium ratio (HR), and other morphological features were measured for adult male specimens following Sæther (1968), Schlee (1966) and Soponis (1977). Abbreviations that are used in this work:

AR antennal ratio: length of last flagellomere / length of remaining flagellomeres; LR leg ratio: length of first tarsal segment/ length of tibia;

BV "Beinverhältnis": length of femur, tibia plus first tarsal segment/ length of tarsal segments 2-5;

SV length of femur plus tibia/ length of tarsal segments 1-3;

L/WR wing length/ wing width ratio;

HR hypopygium ratio: length of gonocoxite/length of gonostylus.

The type specimens are deposited in NMNH (National Museum of Natural History, Washington DC, USA). For each specimen, voucher ID is given as 'YI-CR-\#\#'.

\section{Taxonomy}

Eukiefferiella endobryonia sp. nov. http://zoobank.org/2EFD6644-44B9-4CF2-8C5F-6E2523DE6CF6 Figs 1, 2

Diagnosis. Adult male with squama with few (two or three) setae; gonostylus with crista dorsalis; hind tibial comb and tibial spurs reduced, outer spur absent. Pupa lacks precorneal setae and respiratory horns; three anal macrosetae consisting of two thinner inner macrosetae and a normal outer macroseta. Larval body setae short; seta interna with five branches deeply divided to the base; mentum with four pairs of lateral teeth and single, wide, truncate median tooth. 


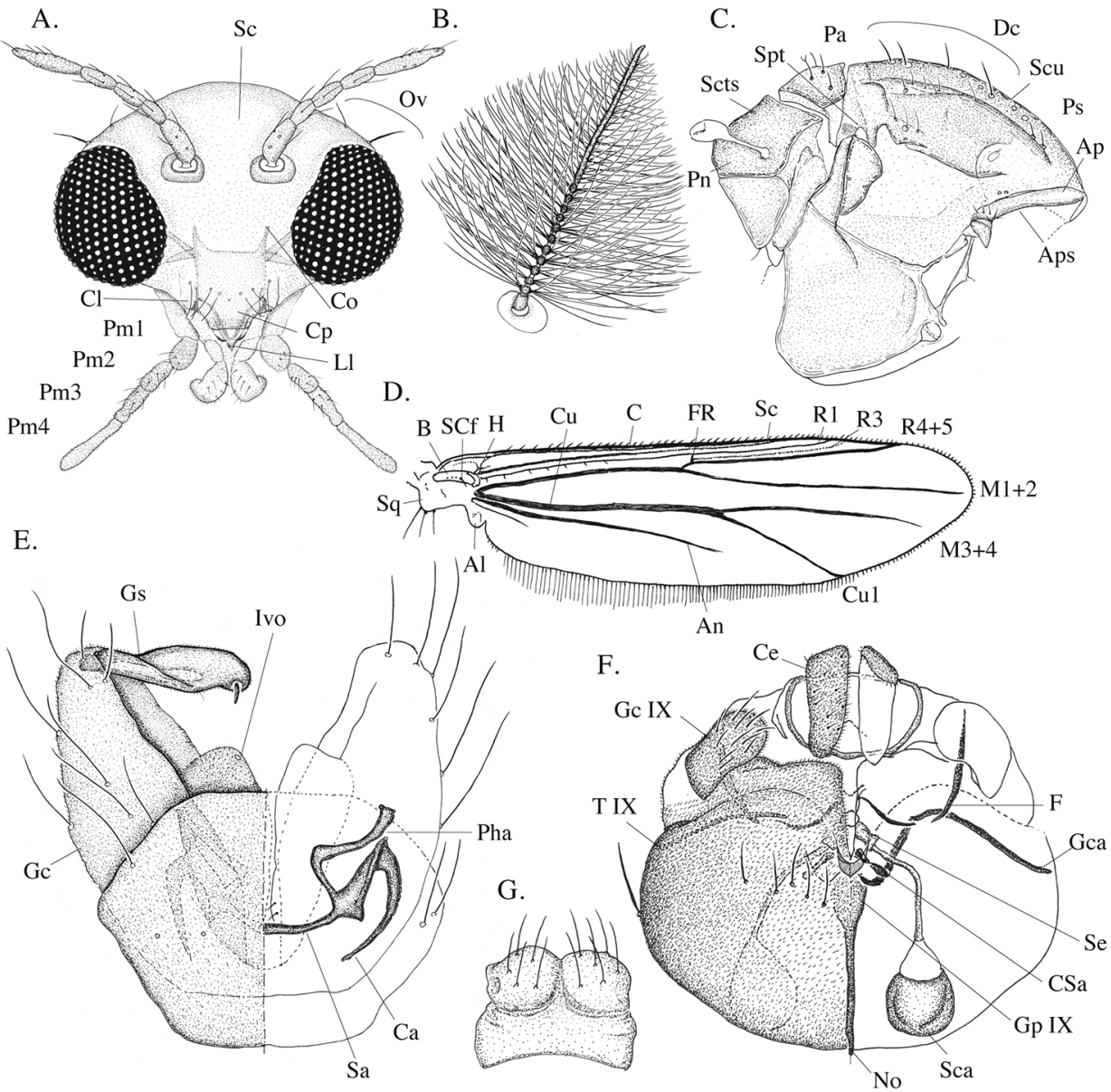

Figure I. Eukiefferiella endobryonia sp. nov., adult. A Female head B male antenna C thorax D right wing $\mathbf{E}$ hypopygium with tergite IX and with left gonocoxite and gonostylus, in dorsal view with gonostylus (left) and in ventral view without gonostylus (right) $\mathbf{F}$ female genitalia, dorsal (left) and ventral view (right) G female tergum IX. Abbreviations (adult). Al: alula; An: anal vein; Ap: antepronotum; Aps: antepronotals; B: brachiolum; C: costa; Ca: coxapodeme; Ce: cercus; Cl: clypeus; Co: cornua; Cp: cibarial pump; Csa: coxosternapodeme; Dc: dorsocentrals; F: fulcrum; Gc: gonocoxite; Gca: gonocozapodeme; Gc IX: gonocoxite IX; Gp IX: gonapophysis IX; Gs: gonostylus; H: humerals; Ivo: inferior volsella; Ll: labial lonchus; No: notum; Pa: prealars; Pha: phallapodeme; Pm: palpal segments; Pn: postnotum; Ps: pseudospurs; Sa: sternapodeme; Sc: subcosta; Sca: seminal capsule; Scts: scutellars; Scu: scutum; Se: spermathecal eminence; Spt: scopula thoracalis; Sq: squama; T IX: tergum IX.

Material examined. Holotype: USA, VA 11 adult male (YI-CR-013); Mountain Lake (37.357627 N 80.534448 W); 24-II-2018 (as larva); Y. Imada leg; emerged as adult on 12-III-2018; NMNH.

Paratypes: USA, VA $\bullet 2$ adult males (YI-CR-009, YI-CR-016) and 3 adult females (YI-CR-010, YI-CR-011, YI-CR-015); Mountain Lake (37.357627N 80.534448W); 


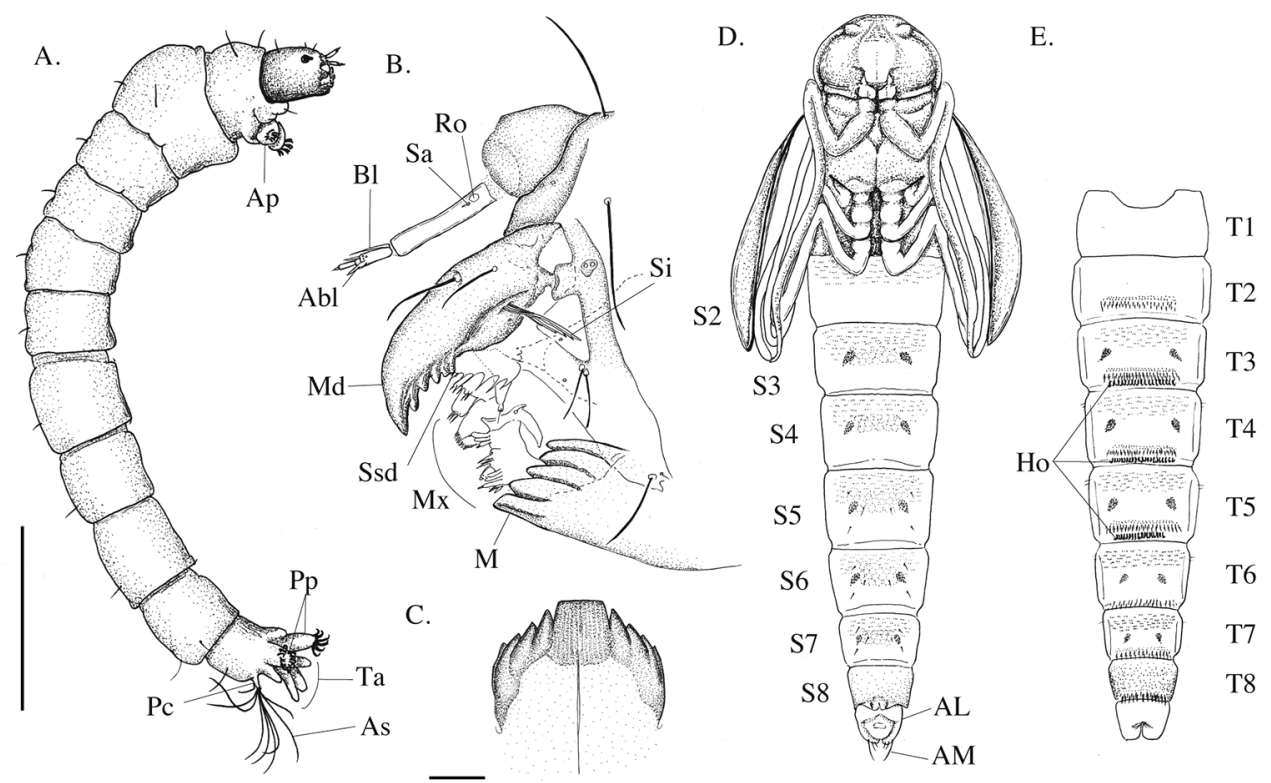

Figure 2. Eukiefferiella endobryonia sp. nov., fourth-instar larva and pupa. Larva (A-C): A general appearance of larva B larval antenna, maxilla and mandible, lateral view $\mathbf{C}$ mentum. Pupa (D, E): D pupa, ventral aspect $\mathbf{E}$ ditto, dorsal aspect. Abbreviations (larva). Abl: accessory blade; Ap: anterior parapods; As: anal seta; Bl: blade; M: mentum; Mx: maxilla; Pc: procercus; Pm: premandible; Pp: posterior parapods; Ro: ring organ; Sa: supraanal seta; Si: seta interna; Ssd: seta subdentalis; Ta: anal tubules. Abbreviations (pupa). Al: anal lobe; Am: anal macroseta; Ho: orally curved hooklets. Scale bars: $0.1 \mathrm{~mm}(\mathbf{C}), 1 \mathrm{~mm}(\mathbf{A})$.

24-II-2018 (as larvae); Y. Imada leg; emerged as adults between 12-III-2018 and 28IV-2018; NMNH.

Other material. USA, TN 2 female pupae (YI-CR-001, YI-CR-002), 2 larvae (YI-CR-006, YI-CR-007); Sparks Lane (35.600894N, 83.794004W); 13-XI-2018 (as larvae); Y. Imada leg; NMNH; VA $\bullet 1$ male pupa (YI-CR-012), 2 female pupa (YI-CR-005, YI-CR-015), 1 pupal exuviae (no voucher), 4 larvae (YI-CR-003, YICR-023, YI-CR-024, YI-CR-025); Mountain Lake (37.357627N, 80.534448W); 9-XI-2018; Y. Imada leg, NMNH.

Egg. Unknown.

First instar larva. Unknown.

Fourth instar larva. $(N=4)$ Body length $3.0 \mathrm{~mm}$. Head capsule dark brown. Body yellowish. Head capsule with frontoclypeal apotome with clypeus without divided by strong suture. Antenna nonretractile, 5-segmented; fourth segment twice as long as third segment; lauterborn organ small; blade as long as flagellum; ring organ in basal third. Premandible with one broad, blunt apical tooth. Mandible with apical tooth longer than first lateral tooth; inner margin smooth, without serrations; seta subdentalis short, peg-like; five very long seta interna with five branches divided nearly to the base, each branch similar in length and width to each other; mola with four long 
spines. Maxilla without pecten galearis; chaetulae of palpiger lacking; lamellae of galea short; anterior lacinial chaeta apparently short, broad-based, more or less differentiated from other chaetae. Mentum with single median tooth and four pairs of lateral teeth; ventromental plates inconspicuous, without beard beneath. Parapods well developed. Claws of anterior parapods all smooth. Procercus unsclerotized, less than 1.5 times as long as wide, without tooth, spur, or seta; anal setae 5-7. Supraanal seta absent. Anal tubules developed, longer than posterior parapods. Body setae very short and inconspicuous, shorter than one-quarter the length of abdominal segments.

Pupa. $(N=8)$ Frontal apotome without frontal seta and warts. Thoracic horn and precorneal seta absent. Dorsocentrals four. Thorax nearly smooth. Wing sheath smooth, without pearl row. T I-II, T VIII, S I and S VIII without shagreen. T II-IX with strong anterior shagreen. S II-VII with weak posterior shagreen. Pedes spurii A and B absent. Caudal spines absent on T II-VIII. S IV-VII female at most with very weak caudal spines. Orally curved hooklets present in uninterrupted rows posterior to caudal spines on T III-V. Apophyses and O setae absent. Segments IV-VIII with very short and weak L-setae. Anal lobe with three unequal anal macrosetae, consisting of two, thinner inner macrosetae and a normal outer macroseta; without median seta, fringe, apical spine.

Adult male. ( $N=3$, if not mentioned) Body length $2.9-3.0 \mathrm{~mm}$ without antenna. Body color dark brown. Antennal length $0.8 \mathrm{~mm}$. Flagellum plumose, with 13 flagellomeres; apex spatula-shaped, without a strong straight seta; antennal groove in male reaching flagellomere 3; AR 1.1. Eye bare. Temporal setae 2, not clearly separated into inner and outer verticals and postorbitals. Postocular setae present in a single row, only behind eyes. Palpus 5-segmented; palpomere lengths: 55-72, 86-90, 96, 159-159 $(N=1)$; palpomeres with 3, 4, 5, 0 setae, respectively. Antepronotum well developed with lobes meeting medially at anterior margin of scutum; dorsal anterpronotals absent; four lateral antepronotals; acrostichals absent; six dorsocentrals in a single row. Approximately three prealars. Scutellum smooth with nine scutellars in single row. Supraalar setae present. Wing length $2.3 \mathrm{~mm}$; L/WR 3.01. Wing membrane glabrous, unmarked. Anal lobe small. Costa not extended. Crossvein $\mathrm{m}$-cu absent. $\mathrm{Cu}_{1}$ straight. $\mathrm{R}_{4+5}$ only fused with $\mathrm{C}$ at apex. $\mathrm{R}_{2+3}$ present, ending at middle of distance between $\mathrm{R}_{1}$ and $\mathrm{R}_{4+5}{ }^{\circ} \mathrm{Cu}_{1}$ very slightly curved apically at wing margin. Squama with two or three setae. Sensilla campaniformia ca. eight at base of brachiolum, three above setae and eight at apex of brachiolum; 1 on $\mathrm{Sc}$, one basally on R, one near base of R1; and one on FR. Calypter without marginal setae; calyptral fringe absent. First tarsomere of foreleg shorter than fore tibia. Fore coxa not enlarged. Hind tibial comb and tibial spurs reduced; outer spur absent. Pulvilli very faint. Gonostylus hinged to gonocoxite and folded inward. Anal point absent. Anterior margin of transverse sternapodeme convex, phallapodeme and aedeagal lobe normal. Virga absent. Gonocoxite with well-developed inferior volsella. Gonostylus with crista dorsalis; apical spine absent. HR 1.99. Lengths of leg segments and leg ratios as in Table 2.

Adult female. $(N=3$, if not mentioned) Body length $2.8 \mathrm{~mm}$. Antenna with five flagellomeres; flagellomere lengths (in $\mu \mathrm{m}$ ): $56.7,35.8,38.2$, 45.2, 101.2; with 2, 3, 2, 3, 3 setae, respectively $(N=1)$. Eye bare. Clypeus with 8 setae. $\mathrm{R}$ with two setae, squama with 4-6 setae. Scutellum as in male. Gonocoxapodemes not jointed me- 
Table 2. Leg segment lengths of adult male specimens of E. endobryonia sp. nov. Data are provided in $\mu \mathrm{m}(\mathrm{N}=1)$. Abbreviations. Fe: femur; Ti: tibia; Ta1-5: tarsal segments 1-5; P1-3: front, mid and hind legs, respectively.

\begin{tabular}{ccccccccccc}
\hline & Fe & Ti & Ta1 & Ta2 & Ta3 & Ta4 & Ta5 & LR & BV & SV \\
\hline P1 & 737.01 & 675.68 & 538.6 & 300.14 & 216.45 & 98.12 & 113.63 & 0.79 & 2.67 & 1.33 \\
P2 & 831.89 & 788.23 & 427.12 & 292.56 & 218.61 & 110.38 & 124.81 & 0.54 & 2.74 & 1.72 \\
P3 & 736.29 & 736.29 & 540.4 & 200.21 & 180.73 & 91.99 & 104.25 & 0.73 & 3.48 & 1.59 \\
\hline
\end{tabular}

sally, well sclerotized. Gonocoxite long, with long and short setae. Tergite IX with two unseparated distinct lobes. Triangular floor under vagina present. Gonapophysis VIII pointed caudally, with two apodeme lobe. Membrane T-shaped. Labia small, bluntly quadrangular, void of microtrichia. Seminal capsule ovoid, darker sclerotized in oral half, without microtrichia. Spermathecal ducts with triangular bulb before separate openings. Cercus normal, length twice as long as width.

Distribution. North America (US: Tennessee, Virginia).

Etymology. The species name is a compound word in which three words from

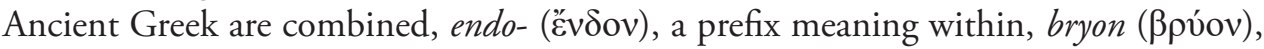
meaning moss, and the suffix $-i a(-i \alpha)$, forming abstract nouns of feminine gender. It alludes to the biology of this species, which live within the case made of mosses.

Remarks. This species is unique among species of Eukiefferiella in that its pupae lack the precorneal seta. This species can also be distinguished from others in the genus by the following combination of traits: pupa lacks respiratory horns, and has the unique configuration of pupal anal macrosetae (two thinner inner macrosetae, a normal outer macroseta); and larva has a mentum with four pairs of lateral teeth and a single, wide, and truncate median tooth. Any geographic variation in this species' characters was detectable between the populations sampled in VA and TN.

DNA barcoding. The results of the species delimitation analyses are summarized in Table 3. First, BLAST search using the partial COI sequence of voucher YICR-001 was executed. This resulted in $98.7 \%$ identical to 'Eukiefferiella sp. voucher BIOUG01648-H02' in GenBank (accession No. KR660601.1) (Telfer et al. 2015); thus, this sequence was included in the following phylogenetic analyses on the assumption that this specimen may belong to E. endobryonia sp. nov. (Table 1). Second, the intra- and inter-specific genetic differentiations were estimated using Bayesian inferences, with the dataset for 28 OTUs. Monophyly of each five species of Eukiefferiella was recovered in the Bayesian phylogeny (Fig. 3), as well as E. endobryonia sp. nov. (95 $\%$ BPP) together with the above-mentioned sequence data. A Bayesian tree indicated that E. endobryonia sp. nov. was sister to E. dittmari among four species of Eukiefferiella in the dataset with significantly high BPP support (Fig. 3). Values of P ID(Strict) for E. endobryonia sp. nov. moderately supported the prediction that this species is correctly identified based on the COI sequence (Table 3). Likewise, P(RD) value exceeded 0.05 and hence the clade distinctiveness was supported (Table 3). However, Rosenberg's $\mathrm{P}_{\mathrm{AB}}$ value was not significant $(\mathrm{P}=0.05)$ and thus the reciprocal monophyly of the clade of $E$. endobryonia sp. nov. was not supported. Two geographic populations sampled, 


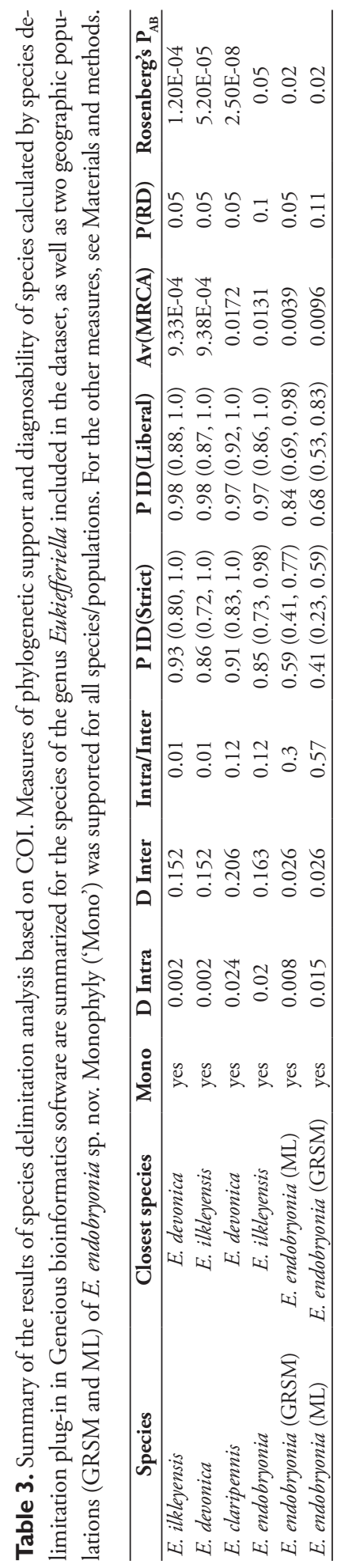




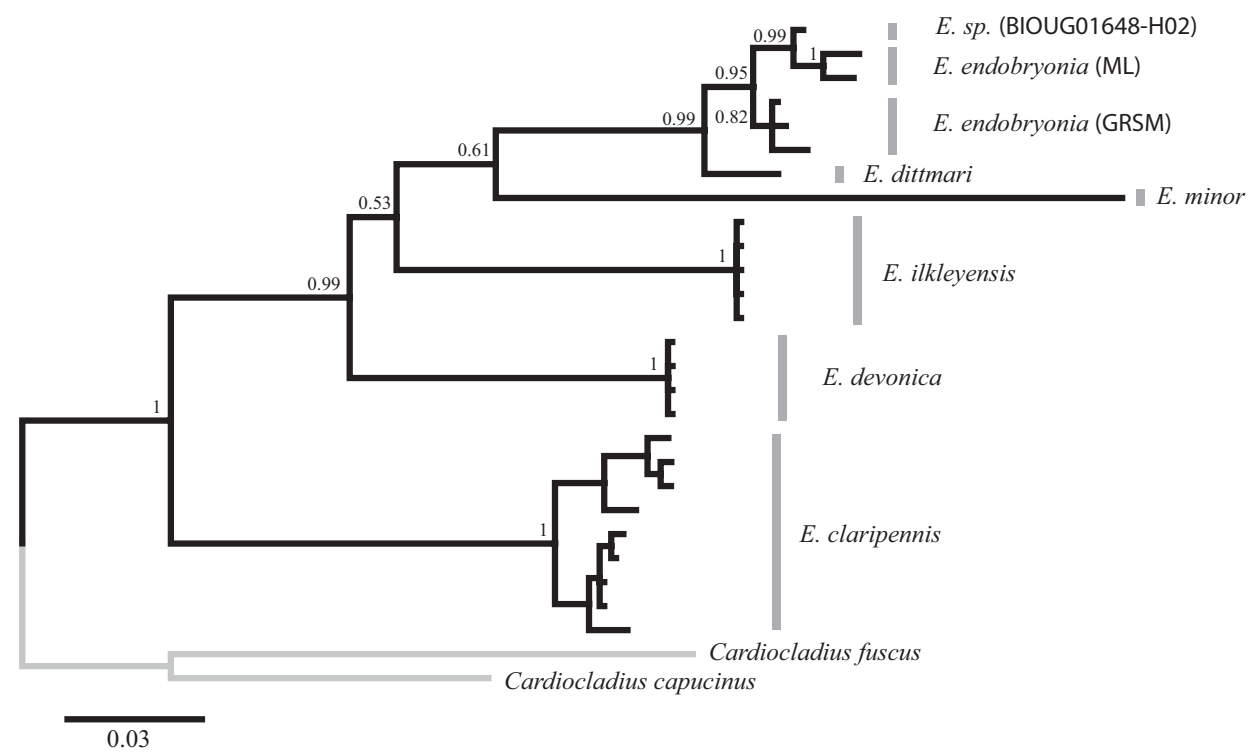

Figure 3. A Bayesian phylogeny based on the COI dataset. Information on the sequences used for this analysis is shown in Table 1. Bayesian Posterior Probabilities were given on each node. Caution is needed to interpret the phylogenetic relationship between and among the members of the species groups (e.g., devonica group, consisting of E. devonica and E. ilkleyensis) included herein, due to the scarcity of available genetic data of the species belonging to the genus Eukiefferiella.

Great Smoky Mountains (GRSM) and Mountain Lake (ML), formed separate clades and between which genetic divergence among population was substantial (Intra/Inter $=0.12$ ) (Table 3), of which values were equivalent to those of the species clade of $E$. claripennis, composed by the specimens from Europe and Canada (Table 3).

Habitat. Larvae of this species occupied slightly different microhabitats in Mountain Lake, VA (Fig. 4A) and Sparks Lane, TN (Fig. 4B). At Mountain Lake, they inhabited a shallow inlet brook flowing into the sink water of the lake. Some leafy and thallose liverworts, including Chiloscyphus (Jungermanniales: Geocalycaceae), as well as some pleurocarpous moss species, such as Brachythecium spp. (Hypnales: Brachytheciaceae), were abundant there on the upper sides of boulders and cobbles that were exposed to spray and occasionally submerged in water. Fontinalis dalecarlica, a host plant species of E. endobryonia sp. nov., occurred at high densities on the lateral sides of submerged boulders in the stream. As a matter of fact, this seemed to be the only aquatic moss species of which conspicuous amounts were found in this particular stream. I was able to find some white-bodied insect larvae occupying some of the apical shoots of Fontinalis moss plants (Fig. 4C) simply by looking in the surface layer of slow-moving, shallow water. Interestingly, these larvae apparently resembled the moss capsules enclosed within the bracts of intact plants at first glance (Fig. 4D). At another locality in TN, the larvae occurred in a stream with fast-flowing water. Some clumps of $F$. novae-angliae were found growing in this rapidly flowing stream, which were 
anchored to the sediment of the streambed. The plants bend $50 \mathrm{~cm}$ below the water surface in riffle habitats. Similar to observations in the other population, larval and pupal cases occurred at the terminal ends of moss shoots of $F$. novae-angliae.

Life history. The life cycle of this new species between late spring and early autumn (May-October) is unknown. This species is likely multivoltine because fourthinstar larvae and pupae were found together at both sites in both April and November. It appears that the larvae were collector-gatherers at the third instar, but became scrapers at the fourth instar (sensu Berg 1995). The third-instar larva restlessly gathered diatoms, which grew on the rims or surfaces of moss leaves. During the later period of the third larval instar, the larva started to dwell on the apical moss shoots and undulated its body among the terminal leaves. Fontinalis leaves are slender, with enrolled margins, and are closely appressed at the tip, forming a semi-enclosed space. At the early stage, a larva showed sinusoidal swimming or undulation behavior (Brackenbury 2000) within the terminal leaves, where it would later make its case. Approximately five days after colonizing the terminal moss leaves, it developed into the fourth larval instar stage (Fig. 4E). The fourth-instar larva seemed incapable of living detached from the case due to its limited locomotory habits. When it was removed from its case, the larva attempted to crawl using the anterior half of its body, but was not able to move forward. It spent most of its time feeding on moss leaves. It extended its head and the anterior part of its body outside of the tube to feed, while using its posterior prolegs to maintain contact with a part of its own tube. It grasped the marginal tissues of moss leaves with its mandibles and dragged them back toward its case (Fig. 4F); simultaneously, silk threads produced from the mouth were extruded with the assistance of the serrated claws of the anterior parapods. The partly grazed leaves were therefore pulled toward the case, which made it easier for the larva to access the surrounding leaf area. The larva repeatedly cut out and fed on the leaves in the bore of the plant in proximity to its case; as a result, ca. 12-20 leaves occurring more or less within ca. $13 \mathrm{~mm}$ from the base of the tube were completely consumed $(N=6)$. The foraging areas were therefore mainly restricted to the region immediately surrounding the tube. This territorial feeding behavior has been reported for many tube-dwelling chironomids (e.g., Darby 1962; Jónasson and Kristiansen 1967; Edgar and Meadows 1969; McLachlan 1977, McAuliffe 1984; Leuchs and Neumann 1990). The larva occasionally defecated, and subsequently immediately ejected the fecal pellet from the end of the tube, which is similar to the behavior of Cladotanytarsus atridorsum (K.) Edw. (Mackey 1976). The larval fecal pellets were long, ca. half of the body length of the larva, and were loose and cylindrical, which allowed them to easily be released into the water. Under laboratory conditions, younger larvae often used the particles originating from the fecal pellets of mature larvae as tube materials (Fig. $4 \mathrm{G}$ ), which means these fecal pellets may also be a source of tube material for younger larvae (Hirabayashi and Wotton 1999). Judging from the composition of fragments in the fecal pellets, at this stage, the larva largely relied on moss leaves as a food source, which is supplemented with fine amorphous detritus and epiphytic diatoms. Under laboratory conditions, the larva only occasionally withdrew into the tube and engaged in lateral undulations of the body therein. 

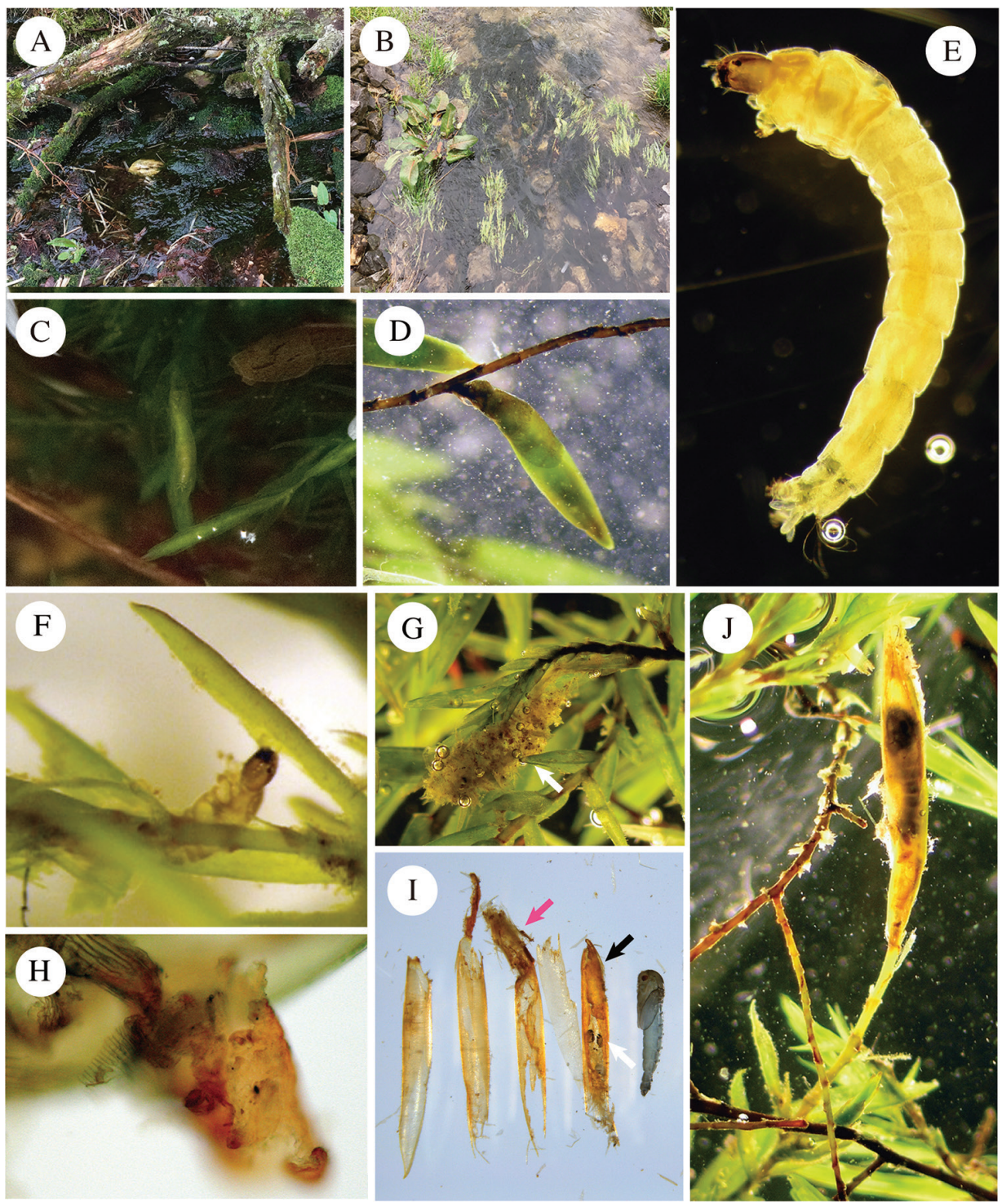

Figure 4. Biology of Eukiefferiella endobryonia sp. nov. A a colony of Fontinalis dalecarlica growing on the sides of pebbles in a gently flowing inlet connected to Mountain Lake, VA, USA (type locality) B a colony of Fontinalis novae-angliae occurring in a rapidly flowing stream at Sparks Lane, TN, USA C early fourthinstar larva, undulating its body in the tube D immature capsule of Fontinalis dalecarlica attached to the stem underwater $\mathbf{E}$ fourth-instar larva $\mathbf{F}$ fourth-instar larva feeding on a leaf margin of $F$. dalecarlica $\mathbf{G}$ a tube structure of the third-instar larva, which was mainly built from particles from the feces of mature larvae $\mathbf{H}$ amorphous, jelly-like silk mass spotted with detritus and diatoms, ripped off of the inner wall of the inner end of the pupal case $\mathbf{I}$ a dissected leaf-rolling case, consisting of five leaves and the resident pupa; the leaves used as the case materials are placed in the order of leaf arrangement, with the outermost leaf at the left-most; the innermost leaf (right next to the pupa) contains the head capsule (white arrow) and exuvium of the fourth-instar larva; some debris (pink arrow) and silk mass (black arrow) stuffed in at both ends can be seen J a pupa in its case: the pupal head is oriented toward the distal end of the shoot tip; most of the leaves near the pupal case were consumed by the larva early in the fourth instar stage. 
The larva became less active in the later period of the fourth instar. It scratched the inner surfaces of the leaf margins, not for consuming the leaves, but presumably for strengthening the case wall. As a result of this intensive fabrication behavior, the tissues of the leaves comprising the case became light brown to red in color due to reactions in the plant tissues, whereas undamaged leaves and stems remained green. Approximately half of the larva's time was spent spinning silk at this point, and the other half was spent staying still. The spinning behavior was stereotyped, regular, and persisted for more than $5 \mathrm{~h}$ at a time. The larva lined the interior of the case with silk, which provided a surface with which the claws of the anal prolegs could engage, anchoring the insect within the case. Due to the fabrication and feeding behavior performed in the earlier stages, there were some apertures in the rolled leaf case on the stem-end side. The larva frequently turned around inside the case to strengthen the case's inside wall. The innermost leaves in the wall, especially at both ends, thus included a thick layer of silk (Fig. $4 \mathrm{H}$ ) as a consequence of continuous silk fabrication. Before entering the prepupal stage, debris containing various particles (fecal pellets, diatoms, and strips of moss leaves) was squashed and accumulated at both ends of the case together with a silk mass to seal the end of the tube (Fig. 4I). At the prepupa stage or later, the case consisted of five or six moss leaves, which were firmly enclosed in silk. The larva molted inside the case and casted off the cuticle; the head capsule and exuvium were thus packed into the posterior end of the pupal case (Fig. 4I). Pupation occurred with the head oriented toward the distal end of the case, without exception $(N=7)$ (Fig. 4J). The pupa rested inside the case throughout most of its development. The pupa then swam toward the surface water and emerged as an adult when its development was completed.

\section{Discussion}

\section{Taxonomic placement of $E$. endobryonia sp. nov.}

Eukiefferiella represents a large and widespread genus of Orthocladiinae (MoubayedBreil and Ashe 2013). This genus was erected by Thienemann (1926), and the independence of this genus from others, as well as the validity of its type species, has been debated in many studies (Edwards 1929; Thienemann 1936; Zavřel 1939; Brundin 1956; Lehmann 1972; Sublette and Wirth 1980). This genus is closely related to some orthocladiine genera in the Cardiocladius group (Sæther and Halvorsen 1981): Cardiocladius Kieff., Tokunagaia Sæth., Tvetenia Kieff., 1922 (Sæther and Halvorsen 1981), Nanocladius Kieff. (Sæther 1977; Lehmann 1972), and Hydrobaenus Fries. Keys for European species of this group are available for larvae (Thienemann 1936; Zavřel 1939; Chernovskii 1949; Bode 1983), pupae (Thienemann 1936; Lehmann 1972), adults (Brundin 1956; Lehmann 1972), and all these stages combined (Sæther and Halvorsen 1981).

The study of the taxonomy of Eukiefferiella is far from complete. Most existing records from the Nearctic are at the genus, or at most the species-group, level (Epler 2001). Ten species have been recorded from North America (Sæther 1969; Sublette 
1970; Simpson and Bode 1980; Oliver et al. 1990; Bode et al. 1996; Patrick 1996; Sandlund and Aagaard 2004; Egan and Ferrington 2015): E. brevinervis (Malloch), E. brevicalcar (Kieff.), E. claripennis, E. coerulescens (Kieff.), E. cyanea Thienemann, E. devonica, E. gracei (Edw.), E. minor, E. unicalcar (Sæth.), and E. pseudomontana Goetghebuer. However, there is also evidently a large number of undescribed species (Cranston et al. 1983; Bode 1983; Merritt and Cummins 1996).

Eukiefferiella endobryonia sp. nov. was assigned to Eukiefferiella on the basis of diagnostic characters proposed by previous studies (Zavřel 1939; Lehmann 1972; Sæther and Halvorsen 1981; Cranston et al. 1983; Bode 1983; Sasa and Kikuchi 1995). Lehmann (1972) suggested that the possession of orally curved hooklets in a row located posteriorly on T III-V is a diagnostic character of the pupae of this genus, although he concluded that there is no single character by which this genus can be defined. Sæther and Halvorsen (1981) emended the definition of Eukiefferiella by comparing it to the other genera of the Cardiocladius group, and distinguished it based on the following features: lack of a male anal point; presence of a hind tibial comb; female gonapophysis VIII undivided; pupa lacking frontal setae, pearl rows, and a median anal seta; and larvae having a simple S I, seta interna, chaetae, and spinulae. Cranston et al. (1983) noted that Eukiefferiella is distinguished from Tvetenia based on a combination of the following larval characters: procercus less than 1.5 times as long as wide; abdominal setae shorter than $1 / 2$ the length of an abdominal segment; and a simple $S$ I.

Eukiefferiella endobryonia sp. nov. is unique in its lack of a precorneal seta, as most of its congeners have three precorneal setae present in a row or triangle (Lehmann 1972; Coffman et al. 1986); also, the configuration of pupal anal macrosetae (inner two macrosetae reduced, and outer one macroseta regular) is apparently unique for the species of Eukiefferiella. The affinity of this new species to others in this genus can thus be problematic. For example, E. endobryonia sp. nov. does not key out into any of the species groups proposed by previous authors (Brundin 1956; Lehmann 1972; Cranston et al. 1983; Bode 1983; Coffman et al. 1986). When compared to the species in Japan, this species may have affinity to chuzeoctava group defined in Sasa and Kikuchi (1995), although squama has only a few setae in this species (as opposed to squama fringed in the species of chuzeoctava group). Some morphological and behavioral traits of E. endobryonia sp. nov. show affinity to those of E. ilkleyensis in the E. devonica group, specifically: the larval mentum medially truncate with four lateral teeth; and the larva of E. ilkleyensis is reported to make a case at the shoot tips of the moss Eurhynchium riparoides (Hedw.) (Brennan and McLachlan 1980). E. ilkleyensis has been recorded from Palaearctic sites (Chernovskii 1949; Brennan and McLachlan 1979; Moller Pillot 2013; Erbaeva and Safronov 2016) but is not known from Nearctic sites. Hence, it is hypothesized that E. endobryonia sp. nov. can be included in the devonica group; importantly, however, this species morphologically contradicts with the distinguishing characters of the devonica group: the pupa of this species does not possess either median antepronotal setae or the row of hooks at the posterior edge of sternite VII (Lehmann 1972); deeply branched seta interna of the larva extending nearly to the base, although shallowly branched seta interna is said to be characteristic of the $E$. 
devonica group (Epler 2001); further, the larval thoracic setae of the new species are less than one-third as long as the segment from which they arise, as opposed to being more than half as long as the corresponding segment in E. ilkleyensis (Chernovskii 1949).

The molecular phylogeny (Fig. 3) clarified that E. endobryonia sp. nov. is genetically well-differentiated from E. ilkleyensis. This species is suggested to be relatively closely related to E. dittmari, which has not been assigned to any species group (Lehmann 1972) but may be incorporated in devonica group (Moller Pillot 2013). E. endobryonia sp. nov. is morphologically distinguished from $E$. dittmari based on the diagnostic character (i.e., the absence of precorneal setae and unequal length of pupal macrosetae in pupa). The immature stages of $E$. dittmari is not described, but the larvae live in mosses (Moller Pillot 2013). Based on the species delimitation analyses, the species clade of $E$. endobryonia sp. nov. was estimated to be distinctive and a significant level of genetic differentiation is detected between the geographic populations sampled (ML and GRSM). However, Rosenberg's $\mathrm{P}_{\mathrm{AB}}$ for each species used herein suggests that the null hypothesis that monophyly of each taxonomic group occurs due to the random coalescent process is not rejected. To clarify the phylogenetic status of the species and to trace the evolutionary history of biology of this group, especially the specialized relationship with mosses, it is necessary to elucidate the biology for the species of which immature stages are unknown and to accumulate morphological and genetic data of the related groups.

\section{Biology of Eukiefferiella}

Eukiefferiella species are generally abundant in the riffles of rivers and streams (Madder et al. 1977; Brennan and McLachlan 1980; Egan et al. 2014), as well as in the littoral zones of lakes (Thienemann 1936). The species of this genus show a broad spectrum of life histories. Brennan and Mclachlan (1980) suggested that the larval feeding or tubedwelling behaviors of species in this group may be affected by their habitats (i.e., riffle zones), as these are locations where the supplies of particles and sediments for tube construction are not always abundant.

Several species of Eukiefferiella are reported to be ectosymbionts of various freshwater invertebrates, including acting as parasites and commensals (Tokeshi 1995), although in many cases these ectosymbionts are not identified at the species level, or may not even have been described yet. An unidentified species in western North America makes silken tubes within the cases of the caddisfly Brachycentrus occidentalis Banks (Trichoptera: Brachycentridae), which may result in a higher mortality rate of the host (Gallepp 1974). E. aneyla Svensson and E. brulini Moubayed-Breil \& Ashe are commensal on limpets of the genus Ancylus Müller (Gastropoda: Ancylidae) (Svensson 1986; Moubayed-Breil and Ashe 2013; Schiffels 2014; Fig. 4E). This genus also includes some species that are commensal on naucorid beetles (Roback 1977; Fig. 4H) or mayflies (Winterbourn 2004). Some species use rocks as substrates, including: $E$. verrallii (Edw.) and E. calvescens (Edw.), which construct loose tubes incorporating rocky particles (Brennan and McLachlan 1980); and E. clypeata Thienemann, which inhabits 
the exposed regions of rocks swept by water currents and builds solid sheets of silk (Brennan and McLachlan 1980) or cobweb-like tubes (Thienemann 1936; Chernovskii 1949) on the surfaces of stones, similarly to the filter net of hydrospsychid caddisflies. Cocoon-making is only known in one species, E. claripennis (Madder et al. 1977).

The larvae of Eukiefferiella are frequently found among aquatic mosses, including Fontinalis spp. (Zavřel 1939; Bode 1983; Suren 1993; Pinder 1995; Callisto et al. 2007). Interestingly, the fourth-instar larvae and pupae of E. ilkleyensis build tubes among the terminal leaves of the long-beaked water feathermoss Eurhynchium riparoides (Hedw.) (Hypnales: Brachytheciaceae) (Brennan and McLachlan 1980). E. ilkleyensis previously showed a preference for Fontinalis moss leaves as case materials (Brennan and McLachlan 1979). Feeding on living and decomposing leaves has been reported for some species (e.g., Callisto et al. 2007). For example, E. ilkleyensis is facultatively phytophagous on Ranunculus calcareus Butcher (Ranunculaceae) in its later larval instars (Berg 1995; Pinder 1995). The moss-feeding and leaf-rolling behaviors of E. endobryonia sp. nov. are apparently related to this species' biological background. Some morphological traits of this species may be associated with their biology, including the secondary loss of the respiratory horns in the pupa. Respiratory horns represent a major morphological adaptation to oxygen-poor environments (Marziali et al. 2006; Marziali and Rossaro 2006), and tubicolous species often have variously shaped respiratory organs that lack a plastron plate (Cranston 1995). Therefore, the pupa of E. endobryonia sp. nov. lacks these additional respiratory adaptations and is dependent on cuticular respiration, although it should be noted that the tubicolous habit itself can be advantageous to respiration (Milne 1938; Walshe 1950; Williams et al. 1987; Kon and Hidaka 1983; Stief et al. 2005).

\section{Examining the diversity of chironomid tube morphotypes}

Building diverse, elaborate tubes is a characteristic behavior of the larvae of Chironomidae. Tube morphology is determined by construction behaviors, which are stereotypical for specific lineages (Chaloner and Wotton 1996; Charbonneau and Hare 1998). Tube construction behavior can therefore be seen as an example of these species' "extended phenotype" (Dawkins 1982). Importantly, spinning in many chironomids is tightly linked with their feeding activity (Wallace and Merritt 1980; Dudgeon 1994; McLachlan and Ladle 2009). In addition, the case morphology of a species is determined by its habitat and the space, substrata, and particle sources available therein (McLachlan and Cantrell 1976; McLachlan 1977; McLachlan et al. 1978; Brennan and McLachlan 1979; Pinder 1986). However, the features of tubes that result from taxon-specific construction behaviors have often been studied with more emphasis on their food types and functional feeding group (Pinder 1986; Berg 1995; Ferrington et al. 2009). Virtually no previous study has ever given a comprehensive account of the diversity of chironomid tube morphology. Herein, I provide a provisional classification of chironomid tube structures based on their morphotypes (see below), with a sum- 
mary of species' biology and some examples. This enables us to give a brief overview of the biology of this group from the perspective of their construction behaviors to deepen our understanding of their ecology and evolution.

Chironomid tube structures can be categorized broadly based on their transportability and the substratum to which the tube is attached. First, tubes can be divided into those with fixed shelters (i.e., the larva cannot move around with the tube) and transportable cases (i.e., the larva freely moves while carrying the tube). Fixed shelters are much more common than transportable cases. Second, fixed shelters can be categorized into three groups (see below) based on the substratum to which the tube is attached. In fact, chironomids as a whole are able to colonize a broad spectrum of substrates. Third, these tube morphotypes can be further subdivided based on the materials out of which the tube is made, but only if the larva has a preference for certain types of particles (e.g., Brennan and McLachlan 1979; Xue and Ali 1997), and most tend to show low specificity for particular tube materials (Brennan and McLachlan 1979).

Tube structure is proximately influenced by the spinning mechanisms of larvae (Webb et al. 1981; Leuchs and Neumann 1990). The silk formation processes differ within the subfamily Chironominae (Webb et al. 1981; Tönjes 1989; Leuchs and Neumann 1990; Ólafsson 1992). Differences in silk properties exist between two subfamilies (i.e., Orthocladiinae and Chironominae) due to the influence of the striated ventromental plates, which are only present in the Chironominae (Churney 1940; Patrick 1966; Webb et al. 1981; Kullberg 1988). Orthocladiine larvae form separate threads of a soft, jelly-like substance, with which they spin loosely woven tubes that are normally attached to hard substrates (Webb et al. 1981). On the contrary, Chironominae manufacture a harder silk that comprises an amorphic liquid secretion while passing the ventromental plates and then becomes a sticky mass in water (Webb et al. 1981). They normally spin compact tubes, in which sediment particles are embedded in a silk matrix (Webb et al. 1981). In addition, some species can produce silk threads with different diameters (Walshe 1951; Leuchs and Neumann 1990), which may be achieved by shearing forces exerted by the ventromental plates or their tensile powers (Leuchs and Neumann 1990).

Chironomid tubes can most commonly be found bound to rocky materials in virtually all types of streams or lake ecosystems. These represent the first major morphotype of tubes: (1) rock material-bound tubes. Rock materials with various grain sizes are used to make tubes, ranging from very coarse (e.g., pebbles, cobbles) to fine (e.g., sand, silt, clay, mud). This type can therefore be subdivided by the grain size of particles used. Soil-dwelling chironomids often occur in lentic or lake environments, where they make soft, cryptic tubes with various lengths and forms, from short, cylindrical tubes to meandering, non-blindly ending tubes, in mud. The shapes of the silk-laden burrows or tubes of species dwelling in soft sediments are associated with their feeding strategies, as these are often deposit- and filter-feeding animals (McLachlan and Cantrell 1976; Leuchs and Neumann 1990; Stief et al. 2005). For example, a mud-dwelling species, Chironomus plumosus (Linn.) (Chironominae: Chironomini) (Fig. 5A), makes tubes with a variety of forms, including U- or J-shaped tubes, or 
horizontal tubes (e.g., McLachlan and Cantrell 1976; McLachlan 1977; LeSage and Harrison 1980; Hodkinson and Williams 1980).

It is noteworthy that three different spinning behaviors are known for species belonging to the genus Chironomus, which correspond to the different feeding strategies used by these species. The first method is found in the filter-feeding $C$. plumosus: the larva spins a funnel-shaped net across the lumen of the tube for filtering fine organic particles out of the water (Walshe 1947, 1951). The second method is another filter-feeding strategy, but is more common than the first type: the larva spins a thin layer of silk on the tube wall and then grazes on the food particles that attach to it inside the tube, together with the old net; the tube walls are thus renewed by the larva spinning new bundles of silk threads (Leuchs and Neumann 1990). The third method is deposit-feeding: the larva builds a cylindrical tube and reaches out of their tube to scrape up food particles from the surrounding sediments (Leuchs and Neumann 1990; Stief et al. 2005).

Some species of this type exhibit an aberrant, more elaborate construction behavior than the others. For example, larvae of Orthocladius (Euorthocladius) rivulorum Kieff. (Fig. 5B) make a suspended tube attached by one end to a riffle rock and feed on diatoms growing on the tube (Hershey et al. 1988; Taylor 1903; Peterson et al. 1993). They convert this tube into a pupal tube by binding the basal part with silk to form a long anchoring strand (Taylor 1903), which is similar to those structures made by limnocentropodid caddisflies (Wiggins 2005). The tubes of $O$. (E.) rivulorum are coated with diatoms, including Hannaea Patrick and Reimer (Fragilariaceae), and exert a considerable effect on the periphytic diatom flora (Pringle 1985; Hershey et al. 1988; Herren et al. 2017). Some Tanytarsini (Chironominae) make rigid tubes, such as Rheotanytarsus Thienemann \& Baus and Lithotanytarsus Thienemann. Rheotanytarsus (Fig. 5C), which make tubes with arms on which the larvae spin silk strands attached to various substrates (Thienemann 1954; Scott 1967; McLachlan 1977; Kullberg 1988; Spies et al. 2009). Lithotanytarsus spp. and Rheotanytarsus reissi (Fig. 5D) spin serpentine tubes on the surfaces of travertine rocks, which become encrusted by carbonate mineral deposits, creating tufa over time (Thienemann 1934, 1936, 1954; Pinder 1995; Burmeister and Reiss 2003). Importantly, some ichnofossils have been interpreted as burrowing tubes from lentic environments (Chamberlain 1975; Rodríguez-Aranda and Calvo 1998; Sanz-Montero et al. 2013), with the oldest example of meandering tubes found in Triassic lake deposits (Voigt and Hoppe 2010). Calcareous columnar tufas resembling the biogenic constructions of Lithotanytarsus spp. have also been recorded in deposits from the Lower Cretaceous or later (Edwards 1936; Pentecost 2005; Brasier et al. 2011).

Chironomids can also colonize a wide range of organisms, which include motile (animals) or sessile (e.g., plants, cyanobacteria) organisms. Information on the tubes formed by symbiotic chironomids is often limited, and their construction behaviors were not described in many previous studies. The second major group of tubes is: (2) tubes on symbiotic animals. Various chironomid lineages (Buchonominae, Podonominae, Chironominae, and Orthocladiinae) exhibit a wide range of symbiotic associations with aquatic animals, ranging from ectoparasitism to phoresis and commensalism, which can be either obligate or facultative associations (Steffan 1968; Tokeshi 1993, 1995; 

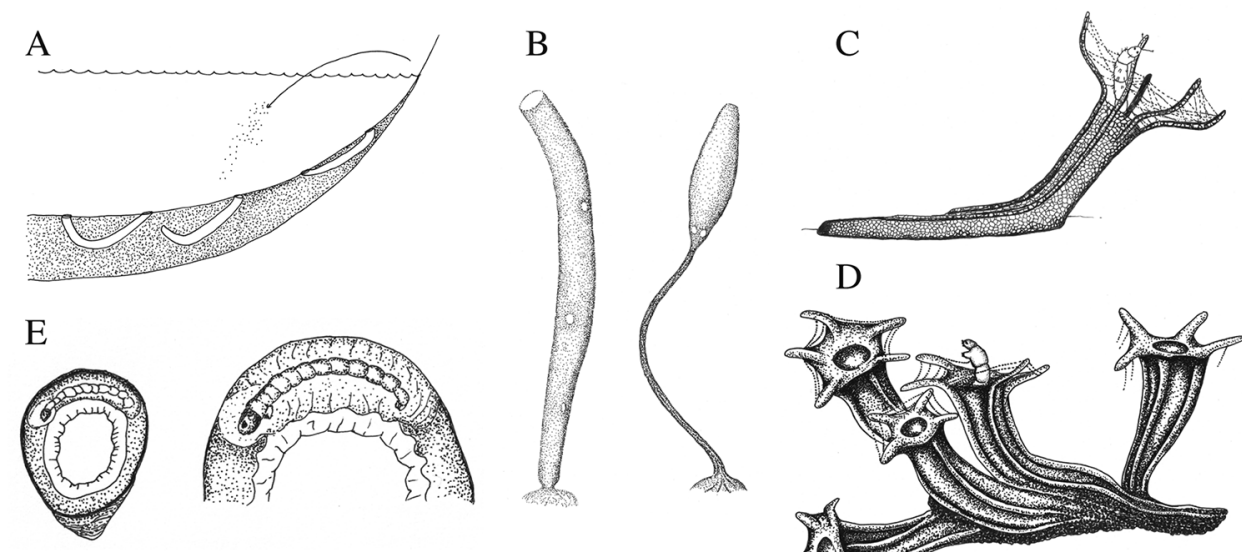

$\mathrm{F}$

G

$\mathrm{H}$
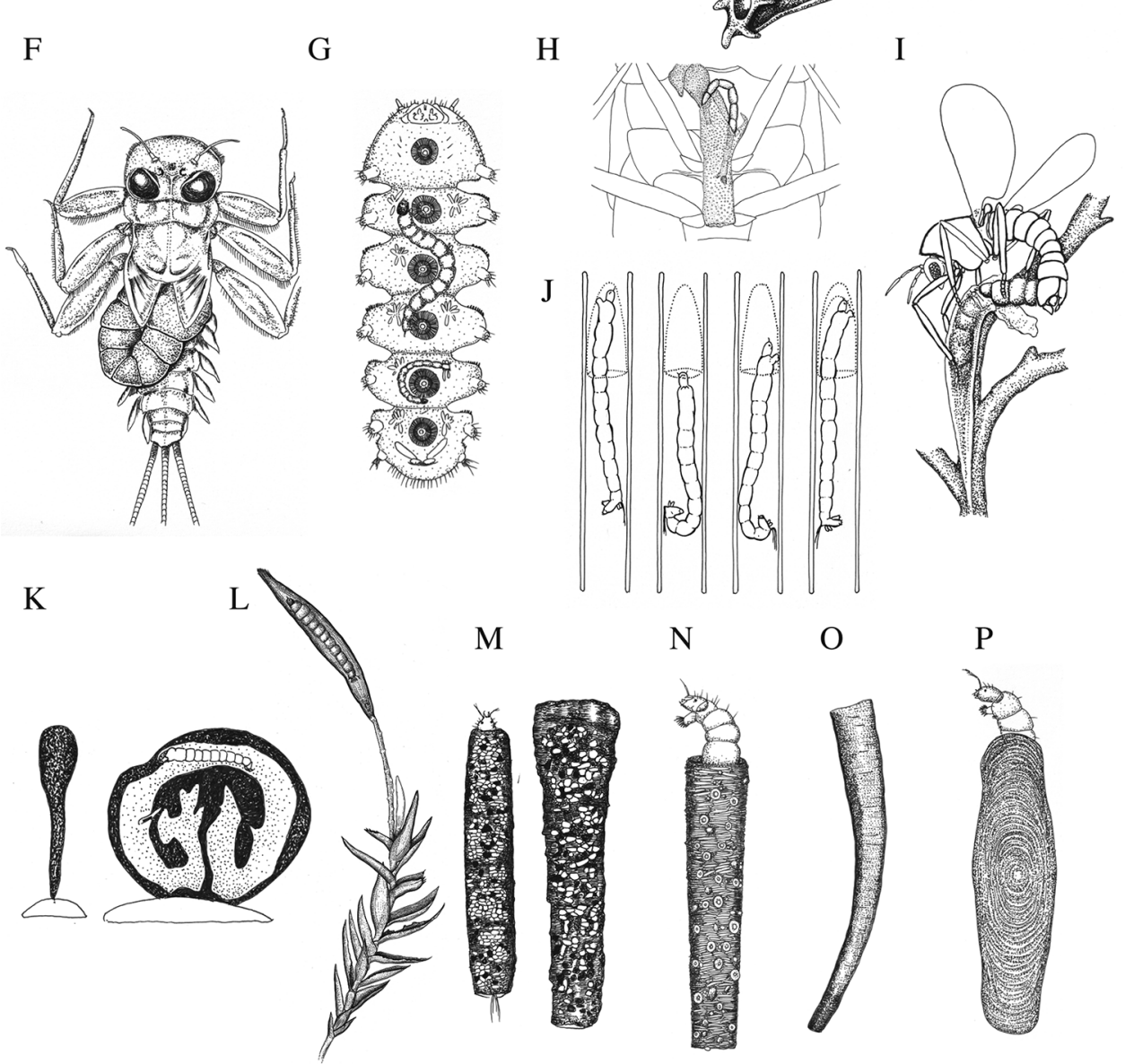

Figure 5. Summary of the biology of chironomids, with special focus on their tube structures. Some taxa without apparent tube structures $(\mathbf{F}, \mathbf{G})$ are included to give some accounts of their biology. Rock materialbound type (A-D): A three types of tubes, U-shaped (left), J-shaped (middle), and open-ended (right), built by the mud-dwelling species Chironomus plumosus, redrawn from McLachlan and Cantrell (1976) B larval (left) and pupal (right) tubes of Orthocladius (Euorthocladius) rivulorum, redrawn from Taylor (1903). 
Schiffels 2014). Their hosts are mainly aquatic invertebrates, including snails (Prat et al. 2004; Fig. 5E), caddisflies (Ashe et al. 2015), mayflies (Claassen 1922; Tonnoir 1922; Codreanu 1939; Thienemann 1954; Jacobsen 1995; Fig. 5F), net-winged midges (Cranston 2007; Fig. 5G), naucorid beetles (Fig. 5H), sponges (da Silva Fernandes et al. 2019), and bryozoans (Moller Pillot 2009; Schiffels 2014). Host selectivity and the site of attachment to the host's body are taxon-specific, and are likely determined by the behavioral patterns of the hosts and the ecological requirements of the chironomids, such as their feeding guilds (Tokeshi 1993). Some species that are tentatively categorized in this group herein presumably do not produce silk (e.g., Symbiocladius, Fig. 5F; Tonnoirocladius, Fig. 5G). The level of dependency on tube construction seems to differ greatly among taxa. For example, species of Symbiocladius (Orthocladiinae) (Fig. 5F) are obligate parasites of mayflies, and their larvae drill under the wing buds of the host and feeds on the host's hemolymph. Symbiocladius spp. are not known to dwell in tubes, but may use other types of attachment mechanisms (Schiffels 2014). Some symbiotic chironomids, particularly facultative symbionts or those that are commensal to the host, tend to make tubes by weaving particles accumulated or flowing in the water on the body surface or shelters of hosts (Schiffels 2014). For example, Winterbourn (2004) gave an account of the tubes of an Eukiefferiella sp. in New Zealand, a commensal midge with a mayfly host, throughout its immature stages, and reported that it used silk thread to attach to the host; however, at the third and fourth larval instars, it built an open-ended silken tube above the mayfly's gills that prevented them from beating, and the wall of this tube incorporated sand grains and fine organic particles.

Similar to the above, the third major category of tubes is: (3) tubes on/within plants, algae, cyanobacteria. Some chironomids in the Orthocladiinae and Chironominae often facultatively make tubes on the external surfaces of plants or algae (McGaha 1952;

Figure 5. Continued. C Rheotanytarsus rivulorum, redrawn from Walshe (1951) D Rheotanytarsus reissi, encrusted to form tufa, redrawn from Burmeister and Reiss (2003). Tubes on symbiotic animals (E-H): E Eukiefferiella brulini on Ancylus fluviatilis, redrawn from Moubayed-Breil and Ashe (2013) F Symbiocladius sp., an obligate parasite of the heptageniid mayfly Heptagenia lateralis, redrawn from Codreanu (1939) G Tonnoirocladius commensalis (Tonnoir), which is commensal to the larvae of the net-winged midge (Blephariceridae), redrawn from Tonnoir (1922) H silk tube of a Neotropical species of Eukiefferiella phoretically attached to Cryphocricos peruvianus De Carlo (Naucoridae), in which the open-ended tube is made between the meso- and meta-thoracic coxae of the host, redrawn from Roback (1977). Tubes on/ within plants, algae, cyanobacteria (I-L): I silk tube made among algae by the marine species Clunio takahashii, shown in copula, redrawn from Hashimoto (1976) J a cone-shaped net constructed in the leaf mine of Endochironomus, redrawn from Walshe (1951) K a tunnel made by Cricotopus nostocicola in a spherical colony of cyanobacteria, Nostoc parmelioides, redrawn from Brock (1960) L a case formed by leaf-rolling on the shoots of Fontinalis mosses by Eukiefferiella endobryonia sp. nov., based on this study. Portable cases (M-P): $\mathbf{M}$ a solid tube composed of fine detritus constructed by Stempellinella minor, redrawn from Brundin (1948) $\mathbf{N}$ a tubular, firmly constructed case armored with diatoms and rhizopod shells constructed by Zavrelia pentatoma, redrawn from Lauterborn (1905) O a slightly curved, conifer needle case of Micropsectra pharetrophora, redrawn from Fittkau and Reiss (1998) P a laterally flattened purse case with concentric growth strips constructed by Lauterborniella agrayloides, redrawn from Lauterborn (1905). 
Berg 1995). For example, species of Telmatogon Schiner (Telmatogetoninae) inhabit intertidal zones and make their tubes within the green algae occurring on rocks (Cranston 2010). Clunio spp. (Orthocladiinae) are marine and make irregular silk tubes dotted with debris on seaweeds, and feed on encrusting diatoms and organic matter (Hashimoto 1976; Archer-Thomson and Cremona 2019). The female adult of Clunio takahashii (Fig. 5I) has a degenerated body and copulates with the male without fully extending her body out of her tube, and subsequently lays eggs in the tube (Hashimoto 1976). Many species in Chironominae and Orthocladiinae live inside plant tissues (Berg 1995), mainly as miners, but also rarely as gall-inducers (Jäger-Zürn et al. 2013). Some leaf-mining genera (Glyptotendipes Kieff., Endochironomus Kieff., and Polypedilum (Pentapedilum) Kieff.) are filter-feeders and spin a conical net inside the mine to filter out floating particles (Fig. 5J), similarly to Chironomus plumosus (Walshe 1951). Species of Stenochironomus Kieff. feed either on living or sequestered plant leaves and tend to show weak preferences for host plants (Kato 2015). Cricotopus nostocicola Wirth (Orthocladiinae) (Fig. 5K) has a symbiotic relationship with colonial cyanobacteria in the genus Nostoc. The larva makes a tube by feeding on globular colonies of Nostoc. The feeding activity of the larva exposes the host to more sunlight, and consequently facilitates photosynthesis by the host (Brock 1960; Dodds and Marra 1989). For many miners (internal-feeders) of plants or algae, silk production has not been confirmed or described. This may be because they are more dependent on their substrates than other taxa. The tube of E. endobryonia sp. nov. (Fig. 5L), as described herein, exemplifies one of the few examples of a chironomid that make a tube exclusively using plant materials with silk. This study showed that the larva of this species dwells among the terminal leaves of moss plants, and draws their body out from the tube to consume all of the leaves occurring within a distance reachable by the larva; this species also forms a pupal case consisting solely of the apical five or six leaves of the moss, which are firmly attached together and internally lined by silk. It is interesting that a congener, E. ilkleyensis, has been reported to make a tube at the shoot terminus of mosses, yet without using silk for construction (Brennan and McLachlan 1979).

The fourth major group of tubes is: (4) portable cases. Among chironomids, transportable cases are far less common than fixed shelters. This is in sharp contrast to the myriad examples of portable cases seen among the Trichoptera (Wiggins 2005). Transportable cases have been found to be made by members of the Chironominae, mainly those in the tribe Tanytarsini, and less commonly in the tribe Chironomini (Walshe 1951; Reiss 1984; Ferrington 1995; Cranston 2010; Stur et al. 2005). Heterotanytarsus apicalis (Kieff.) is the only species so far known to the make portable cases among the species in the Orthocladiinae (Moog 1995; Moller Pillot 2013). Many genera of the subtribe Zavreliina in the tribe Tanytarsini, such as Stempellina Thienemann \& Bause, Stempellinella Brundin (Fig. 5M), and Zavrelia Kieff. (Fig. 4N), live in cool mountain streams and construct heavy cases with hard shells composed of sand or silt (Lauterborn 1905; Hudson et al. 1990; Stur et al. 2005; Lenz 1924; Ekrem and Stur 2009; Namayandeh et al. 2016). Lauterborn (1905) described a cylindrical case made by Zavrelia pentatoma Kieffer \& Bause (Fig. $5 \mathrm{~N}$ ), the surface of which was armored 
with diatoms and rhizopod shells; this species can also build cases exclusively out of rocks (Thienemann 1954). In the subtribe Tanytarsina (Tanytarsini), Calopsectra Kieff. and Micropsectra pharetrophora Fittkau \& Reiss (Chironominae: Tanytarsini) (Fig. 5O) build 'conifer-needle' shaped case with spirally arranged sand grains, silt, and long pieces of detritus, especially diatom frustules (Fittkau and Reiss 1998). A few genera of Chironomini, such as Lauterborniella Thienemann \& Bause and Zavreliella Kieff., also make motile cases with sand or silt particles (Thienemann 1954; Moller Pillot 2009). Lauterborniella agrayloides (Kieff.) (Fig. 5P) makes a soft purse- or spindle-shaped case that is slightly widened in the middle, strongly pressed together laterally, and rounded at both ends; it also contains characteristic concentric growth strips composed of numerous materials. This case resembles those of hydroptilid caddisflies (Lauterborn 1905). The construction behaviors and preferences for case materials of chironomids that make motile cases have largely not been investigated.

As seen above, many chironomid tubes are comparable to those of caddisflies. Not only are the forms of portable cases made by caddisflies and chironomids similar, but there are also notable shared characters of the pupal cases, known as 'silken closures' in caddisflies, between these groups (Wiggins 2005). Diverse forms of silken closures are known among many species of caddisflies in the suborder Integripalpia (Wiggins 2005). These silken closures are disc-shaped masses of silk that are used for closing an open end of the case, and are spun by the final-instar larva before entering pupation. Analogous structures, called 'Verschlußdeckel (closure cap)' or 'Vorderdeckel (front cover)' by Thienemann (1954), were described in some chironomids by previous studies (Lauterborn 1905; Lenz 1924). This represents a remarkable example of convergent evolution in portable case-makers in two distantly related insect clades (chironomids and caddisflies).

Tube morphotypes can be a tool for use in research in the taxonomy, ecology, and evolution of tube-building animals. The morphotypes of tubes should be assessed if they are useful for taxonomy. The tube, as a functional trait of a specific taxonomic group, may also be useful for examining different species' ecological niches within a community (McGill et al. 2006). From an ecological perspective, tube functions have been and will continue to be an important subject at various scales, ranging from their adaptive significance for tube-dwelling individuals or species (e.g., Walde and Davies 1984; Williams et al. 1987) to their ecological impacts at the community or ecosystem scales (e.g., Ólafsson and Paterson 2004).

Herein, I made the simplistic assumption that the evolution of case-construction behavior in chironomids could be estimated based on the results of a previous molecular phylogenetic study (Cranston et al. 2012), although the phylogeny of this group has historically been contentious. Buchonominae was recovered as the most plesiomorphic subfamily (Murray and Ashe 1985; Cranston et al. 2012), although this contradicted some previous studies' conclusions (e.g., Sæther 2000). Importantly, Buchonomyia spp. (Buchonominae) are ectoparasites of caddisflies, and supposedly do not manipulate silk (Ashe et al. 2015). The early diverging subfamilies identified, including Podonominae and Tanypodinae, are free-living (Moller Pillot 2013). Among extant lineages, Telmatogetoninae is likely to be one of the earliest-diverging clades of case-builders (Cranston 
et al. 2012). Tube diversity and construction behavior have evidently diversified in two more derived subfamilies, Chironominae and Orthocladiinae, which split during the mid-Jurassic. Interestingly, the spinning mechanism and silk properties are apparently different among the three clades of tube-making chironomids (Leuchs and Neumann 1990). The different ecological settings and evolutionary backgrounds of these groups have led to them developing a wide range of construction behaviors that have not yet been addressed within a geochronological framework. The emergence of two currently dominant and diverse clades of decomposers (i.e., caddisflies and chironomids) is estimated to have occurred in the Early Triassic (Cranston et al. 2012; Malm et al. 2013). Further, it has been suggested that the major clades of case-builders in both clades appeared contemporaneously during or after the Late Jurassic (Malm et al. 2013). The behavioral convergence of these tube-making insects may have been associated with major changes in freshwater ecosystems that occurred through geological time, such as increased allochthonous inputs of coarse plant materials and fine detritus into these systems (Lancaster and Downes 2013). It would be interesting to examine how these clades of ecosystem engineers have contributed to, or been affected by, the drastic changes in the trophic structures of stream and lake ecosystems that occurred in the Mesozoic Era (Lancaster and Downes 2013; Minter et al. 2016; Buatois et al. 2016; Savrda 2019).

The tube morphology of chironomids does indeed show significant diversity. It is likely that lability in silk production, particle and substrate selection, and construction behavior has made it possible for chironomids to use a broad array of ecological niches, as is the case for the Trichoptera (Weaver and Morse 1986; Wiggins and Mackay 1978; Mackay and Wiggins 1979; Wiggins 2005; Morse et al. 2019). Future investigations of the evolution and diversification of construction behaviors in chironomids in relation to changes in available habitat types will be important to improve our understanding of the evolution of aquatic ecosystems.

\section{Acknowledgements}

I sincerely wish to thank Dr. Conrad C. Labandeira for his thoughtful support throughout my tenure at the National Museum of Natural History, for providing the laboratory supplies and equipment used, and for assisting with field sampling. I also gratefully acknowledge the assistance of the interlibrary loan staff of Ehime University Library for collecting literature. Thanks are also due to Dr. Michael Donovan for helping take care of the insects in the laboratory; Dr. Hiroki Hata for initial assistant of using the software packages for analysis of genetic data; Drs. Koichiro Kawai and Athol McLachlan for providing valuable information on chironomid taxonomy and tube structures, respectively; Drs. Charles Watson, Athol McLachlan, and Fabio Laurindo da Silva for reviewing the manuscript and for providing constructive comments; the staff at Mountain Lake Biological Station and of the National Park Service at Great Smoky Mountains National Park for allowing sampling in these areas. I would also like to thank Editage (www.editage.com) for English language editing. This study was 
made possible with support from the Yoshida Scholarship Foundation, a research grant for Environmental Field Research by the Asahi Glass Foundation, and Grant-in-Aid for Research Activity Start-up Grant Number JP18H06077.

\section{References}

Akaike H (1973) Information theory as an extension of the maximum likelihood principle. In: Csaksi FPB (Ed.) $2^{\text {nd }}$ International Symposium on Information Theory. Akademiai Kaido, Budapest, 267-281. https://doi.org/10.1007/978-1-4612-1694-0_15

Archer-Thomson J, Cremona J (2019) Rocky Shores, British Wildlife Collection Book 7 , Bloomsbury Wildlife, London, 384 pp.

Ashe P, O'Connor J, Murray D (2015) A review of the distribution and ecology of Buchonomyia thienemanni Fittkau (Diptera: Chironomidae) including a first record for Russia. European Journal of Environmental Science 5(1):5-11.https://doi.org/10.14712/23361964.2015.69

Berg M (1995) Larval food and feeding behavior. In: Armitage P, Cranston PS, Pinder LCV (Eds) The Chironomidae - the biology and ecology of non-biting midges. Springer Netherlands, Netherlands, 136-168. https://doi.org/10.1007/978-94-011-0715-0_7

Bode RW (1983) Larvae of North American Eukiefferiella and Tvetenia (Diptera: Chironomidae). Bulletin 452, New York State Museum, New York, 48 pp.

Bode RW, Novak MA, Abele LE (1996) Quality assurance work plan for biological stream monitoring in New York State. NYS Department of Environmental Conservation, Albany, New York, 79 pp. https://www.eighteenmilerap.com/BIO3_QAPP\%20for\%20Biological\%20Stream\%20Monitoring\%20in\%20NYS.pdf

Bogut I, Vidakovic J, Cerba D, Palijan G (2009) Epiphytic meiofauna in strands of different submerged macrophytes. Ekoloji 18(70): 1-9. https://doi.org/10.5053/ekoloji.2009.701

Brackenbury J (2000) Locomotory modes in the larva and pupa of Chironomus plumosus (Diptera, Chironomidae). Journal of Insect Physiology 46(12): 1517-1527. https://doi. org/10.1016/S0022-1910(00)00079-2

Brasier A, Andrews J, Kendall A (2011) Diagenesis or dire genesis? the origin of columnar spar in tufa stromatolites of central Greece and the role of chironomid larvae. Sedimentology 58(5): 1283-1302. https://doi.org/10.1111/j.1365-3091.2010.01208.x

Brennan A, McLachlan AJ (1979) Tubes and tube-building in a lotic chironomid (Diptera) community. Hydrobiologia 67(2): 173-178. https://doi.org/10.1007/BF00126716

Brennan A, McLachlan AJ (1980) Species of Eukiefferiella Thienemann (Dipt., Chironomidae) from a northern river with notes on larval dwellings. The Entomologist's Monthly Magazine 116: 109-111.

Brock E (1960) Mutualism between the midge Cricotopus and the alga Nostoc. Ecology 41(3): 474-483. https://doi.org/10.2307/1933322

Brundin L (1948) Über die Metamorphose der Sectio Tanytarsariae connectens (Dipt. Chironomidae). Arkiv för zoologi 41: 1-22.

Brundin L (1956) Zur Systematik der Orthocladiinae (Dipt. Chironomidae). Report of the Institute of Fresh water Research, Drottningholm 37: 5-185. 
Buatois LA, Labandeira CC, Mángano G, Cohen A, Voigt S (2016) The Mesozoic lacustrine Revolution. In: Mángano MG, Buatois LA (Eds) The trace-fossil record of major evolutionary events. Topics in Geobiology 40, Springer Netherlands, Netherlands, 179-263. https://doi.org/10.1007/978-94-017-9597-5_4

Bunn SE, Barton DR, Hynes HBN, Power G, Pope MA (1989) Stable isotope analysis of carbon flow in a tundra river system. Canadian Journal of Fisheries and Aquatic Sciences 46: 1769-1775. https://doi.org/10.1139/f89-224

Burmeister E-G, Reiss F (2003) Rheotanytarsus reissi, eine zweite tuff bildende Wasserinsektenart (Diptera, Chironomidae). Lauterbornia 48: 77-88. https://doi.org/10.5324/fn.v31i0.1375

Callisto M, Gonçalves JF, Graça MAS (2007) Leaf litter as a possible food source for chironomids (Diptera) in Brazilian and Portuguese headwater streams. Revista Brasileira de Zoologia 24(2): 442-448. https://doi.org/10.1590/S0101-81752007000200023

Chaloner DT, Wotton RS (1996) Tube building by larvae of 3 species of midge (Diptera: Chironomidae). Journal of the North American Benthological Society 15(3): 300-307. https://doi.org/10.2307/1467278

Chamberlain C (1975) Recent Lebensspuren in nonmarine aquatic environments. In: Frey RW (Ed.) The study of trace fossils: a synthesis of principles, problems, and procedures in ichnology, Springer-Verlag New York Inc., New York, 431-458. https://doi.org/10.1007/9783-642-65923-2_19

Chapin III FS (2011) Decomposition and ecosystem carbon budgets. In: Chapin III FS, Matson PA, Vitousek P (Eds) Principles of terrestrial ecosystem ecology. Springer Science+Business Media, New York, 183-228. https://doi.org/10.1007/978-1-4419-9504-9_7

Charbonneau P, Hare L (1998) Burrowing behavior and biogenic structures of mud-dwelling insects. Journal of the North American Benthological Society 17(2): 239-249. https://doi. org/10.2307/1467965

Chernovskii AA (1949) Identification of larvae of the midge family Tendipedidae. [English translation of Russian by Lees E Freshwater Biological Association, Marshall KE (Ed.) 1961.] National Lending Library of Science and Technology, Boston Spa, Yorkshire, 293 pp.

Churney L (1940) A contribution to the anatomy and physiology of the salivary gland system in the larva of Chironomus (Diptera). Journal of Morphology 66(2): 391-407. https://doi. org/10.1002/jmor.1050660211

Claassen M (1922) The larva of a chironomid (Trissocladius equitans n. sp.) which is parasitic upon a may-fly nymph (Rithrogena sp.). The University of Kansas Science Bulletin 14(16): 395-405. https://archive.org/details/biostor-99417

Codreanu R (1939) Recherches biologiques sur un Chironomide, Symbiocladius rhithrogenae (Zav.) ectoparasite "cancérigène" des Ephémères torrentocoles. Archives de zoologie expérimentale et générale 81: 1-283.

Coffman WP, Cranston PS, Oliver DR, Sæther OA (1986) Keys and diagnoses of the pupae of the subfamily Orthocladiinae (Diptera, Chironomidae). Entomologica Scandinavica Supplementum 28: 147-296.

Courtney GW, Pape T, Skevington JH, Sinclair BJ (2017) Biodiversity of Diptera. In: Foottit RG, Adler PH (Eds) Insect biodiversity: science and society, Volume I, $2^{\text {nd }}$ edn. WileyBlackwell, New Jersey, 229-278. https://doi.org/10.1002/9781118945568.ch9 
Cranston PS (1995) Morphology. In: Armitage PD, Cranston PS, Pinder LCV (Eds) The Chironomidae - Biology and ecology of non-biting midges. Springer Netherlands, Netherlands, 297-335. https://doi.org/10.1007/978-94-011-0715-0_2

Cranston PS (2007) The identity of Dactylocladius commensalis (Diptera: Chironomidae) revealed. Aquatic Insecits 29(2): 103-114. https://doi.org/10.1080/01650420701308844

Cranston PS (2010) Chirokey. www.chirokey.skullisland.info/ [Accessed on 7.IX.2019

Cranston PS, Hardy N, Morse G (2012) A dated molecular phylogeny for the Chironomidae (Diptera). Systematic Entomology 37(1): 172-188. https://doi.org/10.1111/j.13653113.2011.00603.x

Cranston FS, Oliver DR, Sæther OA (1983) The larvae of Orthocladiinae (Diptera: Chironomidae) of the Holarctic region-keys and diagnoses. In: Wiederholm T (Ed.) Chironomidae of the Holarctic region. Part I. Larvae, Entomologia Scandinavica Supplementum 19: 149-291.

Cummins KW (1974) Structure and function of stream ecosystems. BioScience 24: 631-641. https://doi.org/10.2307/1296676

Darby R (1962) Midges associated with California rice fields, with special reference to their ecology. Hilgardia 32(1): 1-206. https://doi.org/10.3733/hilg.v32n01p001

da Silva Fernandes IS, Nicacio G, Rodrigues GG, da Silva FL (2019) Freshwater spongedwelling Chironomidae (Insecta, Diptera) in northeastern Brazil. Biotemas 32(1): 39-48. https://doi.org/10.5007/2175-7925.2019v32n1p39

Dawkins R (1982) The extended phenotype: the gene as the unit of selection. Oxford University Press, New York, 320 pp.

Dodds W, Marra J (1989) Behaviors of the midge, Cricotopus (Diptera: Chironomidae) related to mutualism with Nostoc parmelioides (Cyanobacteria). Aquatic Insects 11(4): 201-208. https://doi.org/10.1080/01650428909361372

Dudgeon D (1994) The functional significance of selection of particles by aquatic animals during building behaviour. In: Wotton RS (Ed.) The biology of particles in aquatic systems. $2^{\text {nd }}$ edn. Lewis Publishers, Boca Raton, Florida, 289-312.

Edgar WD, Meadows PS (1969) Case construction, movement, spatial distribution and substrate selection in the larva of Chironomus riparius Meigen. Journal of Experimental Biology 50: 247-253. https://jeb.biologists.org/content/50/1/247.abstract

Edwards FW (1929) British non-biting midges. Transactions of the Royal Entomological Society of London 77: 279-430. https://doi.org/10.1111/j.1365-2311.1929.tb00692.x

Edwards WN (1936) A Pleistocene chironomid-tufa from Crémieu (Isère). Proceedings of the Geologists' Association 47(3): 197-198. https://doi.org/10.1016/S0016-7878(36)80003-0

Egan AT, Ferrington LC (2015) Chironomidae (Diptera) in freshwater coastal rock pools at Isle Royale, Michigan. Transactions of the American Entomological Society 141(1): 1-25. https://doi.org/10.3157/061.141.0102

Egan AT, Lafrancois T, Edlund MB, Ferrington LC, Glase J (2014) Biological studies and mapping of shoreline rock pools in three Lake Superior national parks. Natural Resource Technical Report NPS/MWRO/NRTR-2014/907. National Park Service, Fort Collins, Colorado, $335 \mathrm{pp}$.

Ekrem T, Stur E (2009) A review of the genus Zavrelia (Diptera: Chironomidae). European Journal of Entomology 106: 119-144. https://doi.org/10.14411/eje.2009.016 
Epler JH (2001) Identification manual for the larval Chironomidae (Diptera) of North and South Carolina. Special Publication SJ 2001-SP13. North Carolina Department of Environment and Natural Resources, Raleigh, North Carolina, 526 pp.

Erbaeva E, Safronov G (2016) Register of Chironomids (Diptera, Chironomidae) of the Lake Khubsugul in Mongolia. Erforschung biologischer Ressourcen der Mongolei 13: 221-224. https:// www.semanticscholar.org/paper/Register-of-Chironomids-(Diptera\%2C-Chironomidae)-ofErbaeva-Safronov/819aa2338056615643cbb59102ead7dfe9a93f69

Ferrington LC (1995) Utilization of anterior headcapsule structures in locomotion by larvae of Constempellina sp. (Diptera: Chironomidae). In: Cranston PS (Ed.) Chironomids: from Genes to Ecosystems, CSIRO, Melbourne, 369-378.

Ferrington LC, Berg MB, Coffman WP (2009) Chironomidae. In: Merritt RW, Cummins KW, Berg MB (Eds) An Introduction to the Aquatic Insects of North America. Fourth Edition. Kendall Hunt Pub. Co., Dubuque, Iowa, 847-989.

Fittkau E, Reiss F (1998) Micropsectra pharetrophora, a new species of Tanytarsini (Diptera, Chironomidae) constructing portable larval cases. Journal of the Kansas Entomological Society 71(3): 226-233. https://www.jstor.org/stable/25085842

Folmer O, Black M, Hoeh W, Lutz R, Vrijenhoek R (1994) DNA primers for amplification of mitochondrial cytochrome c oxidase subunit I from diverse metazoan invertebrates. Molecular Marine Biology and Biotechnology 3: 294-299. https:/www.semanticscholar.org/ paper/DNA-primers-for-amplification-of-mitochondrial-c-I-Folmer-Black/943d38b9d96 f8222e883604822bcafb7930ca6da

Gall J-C (1983) Ancient Sedimentary Environments and the Habitats of Living Organisms: Introduction to Palaeoecology. Springer-Verlag, Berlin Heidelberg, 222 pp. https://doi. org/10.1007/978-3-642-68909-3

Gallepp GW (1974) Behavioral ecology of Brachycentrus occidentalis Banks during the pupation period. Ecology 55: 1283-1294. https://doi.org/10.2307/1935456

Guryev V, Makarevitch I, Blinov A, Martin J (2001) Phylogeny of the genus Chironomus (Diptera) inferred from DNA sequences of mitochondrial Cytochrome b and Cytochrome oxidase I. Molecular Phylogenetics and Evolution 19(1): 9-21. https://doi.org/10.1006/mpev.2001.0898

Hashimoto H (1976) Non-biting midges of marine habitats (Diptera: Chironomidae). In: Cheng L (Ed.) Marine Insects. North-Holland Publishing Company, Amsterdam, Netherlands, 377-414. https://escholarship.org/uc/item/1pm1485b\#main

Heckman CW (2018) Insects that construct underwater shelters. In: Heckman CW (Ed.) Ecological Strategies of Aquatic Insects. CRC Press, Boca Raton, Florida, 106-118. https:// doi.org/10.1201/9781315119892-7

Herren CM, Webert KC, Drake MD, Zanden MJV, Einarsson Á, Ives AR, Gratton C (2017) Positive feedback between chironomids and algae creates net mutualism between benthic primary consumers and producers. Ecology 98(2): 447-455.

Hershey AE (1987) Tubes and foraging behavior in larval Chironomidae: implications for predator avoidance. Oecologia 73(2): 236-241. https://doi.org/10.1007/BF00377513

Hershey AE, Hiltner AL, Hullar MAJ, Miller MC, Vestal JR, Lock MA, Rundle S (1988) Nutrient influence on a stream grazer: Orthocladius microcommunities respond to nutrient input. Ecology 69(5): 1383-1392. https://doi.org/10.2307/1941635 
Hinton H (1951) A new chironomid from Africa, the larva of which can be dehydrated without injury. Proceedings of the Zoological Society of London 121(2): 371-380. https://doi. org/10.1111/j.1096-3642.1951.tb00801.x

Hirabayashi K, Wotton RS (1999) Organic matter processing by chironomid larvae (Diptera: Chironomidae). Hydrobiologia 382: 151-159. https://doi.org/10.1023/A:1003472329603

Hodkinson LD, Williams KA (1980) Tube formation and distribution of Chironomus plumosus L. (Diptera: Chironomidae) in a eutrophic woodland pond. In: Murray DA (Ed.) Chironomidae: Ecology, Systematics, Cytology and Physiology, Pergamon Press, Oxford, 331-337. https://doi.org/10.1016/B978-0-08-025889-8.50051-9

Hölker F, Vanni M, Kuiper JJ, Meile C, Grossart H-P, Stief P, Adrian R, Lorke A, Dellwig O, Brand A, Hupfer M, Mooij WM, Nützmann G, Lewandowski J (2015) Tube-dwelling invertebrates: tiny ecosystem engineers have large effects in lake ecosystems. Ecological Monographs 85(3): 333-351. https://doi.org/10.1890/14-1160.1

Hudson PL, Lenat DR, Caldwell BA, Smith D (1990) Chironomidae of the southeastern United States: a checklist of species and notes on biology, distribution, and habitat. US Fish \& Wildlife Service, Fish and Wildlife Research 7, Washington, 52 pp.

Huelsenbeck JP, Ronquist F (2001) MrBaYes: Bayesian inference of phylogenetic trees. Bioinformatics 17(8): 754-755. https://doi.org/10.1093/bioinformatics/17.8.754

Jacobsen R (1995) Symbiotic associations between Chironomidae (Diptera) and Ephemeroptera. In: Corkum L, Ciborowski J (Eds) Current Directions in Research on Ephemeroptera. Canadian Scholars' Press, Inc., Toronto, 317-332.

Jónasson PM, Kristiansen J (1967) Primary and secondary production in Lake Esrom. Growth of Chironomus anthracinus in relation to seasonal cycles of phytoplankton and dissolved oxygen. Internationale Revue der gesamten Hydrobiologie und Hydrographie 13: 139-162. https://doi.org/10.1002/iroh.19670520203

Jäger-Zürn I, Spies M, Philbrick CT, Bove CP, Mora-Olivo A (2013) Plant galls (cecidia) in the neotropical water plant family Podostemaceae induced by larvae of Chironomidae. Spixiana 36(1): 97-112. https://www.zobodat.at/pdf/Spixiana_036_0097-0112.pdf

Kato M (2015) Intense inhabitation and relaxed host-leaf preference of aquatic chironomid leaf-miners in headwater streams in Asian lucidophyllous forests. Journal of Natural History 49(31-32): 1891-1903. https://doi.org/10.1080/00222933.2015.1006279

Kearse M, Moir R, Wilson A, Stones-Havas S, Cheung M, Sturrock S, Buxton S, Cooper A, Markowitz S, Duran C, Thierer T, Ashton B, Meintjes P, Drummond A (2012) Geneious basic: an integrated and extendable desktop software platform for the organization and analysis of sequence data. Bioinformatics 28: 1647-1649. https://doi.org/10.1093/bioinformatics/bts199

Kon M, Hidaka T (1983) Chimney projecting behavior of chironomid larvae (Chironomus yoshimatsui; Diptera, Chironomidae). Journal of Ethology 1(1-2): 111-113. https://doi. org/10.1007/BF02347838

Kikawada T, Minakawa N, Watanabe M, Okuda T (2005) Factors inducing successful anhydrobiosis in the African chironomid Polypedilum vanderplanki: significance of the larval tubular nest. Integrative and Comparative Biology 45(5): 710-714. https://doi.org/10.1093/ $\mathrm{icb} / 45.5 .710$ 
Kullberg A (1988) The case, mouthparts, silk and silk formation of Rheotanytarsus muscicola Kieffer (Chironomidae: Tanytarsini). Aquatic Insects 10(4): 249-255. https://doi. org/10.1080/01650428809361336

Kumar S, Stecher G, Tamura K (2016) MEGA7: molecular evolutionary genetics analysis version 7.0 for bigger datasets. Molecular Biology and Evolution 33(7): 1870-1874. https:// doi.org/10.1093/molbev/msw054

Lancaster J, Downes B (2013) Evolution, biogeography, and aquatic insect distributions. In: Lancaster J, Downes BJ (Eds) Aquatic Entomology. Oxford University Press, New York, 20-36. https://doi.org/10.1093/acprof:oso/9780199573219.003.0002

Lauterborn R (1905) Zur Kenntnis der Chironomiden-Larven. Zoologischer Anzeiger 29(7): 207-217.

Lawton JH, Jones CG (1995) Linking species and ecosystems: organisms as ecosystem engineers. In: Jones CG, Lawton JH (Eds) Linking species and ecosystems. Chapman and Hall, London, 141-150. https://doi.org/10.1007/978-1-4615-1773-3_14

Lehmann J (1972) Revision der europaischen Arten (Puppen und Imagines der Gattung Eukiefferiella Thienmann. (Diptera: Chironomidae). Beiträge zur Entomologie 22(7/8): 347405. https://doi.org/10.21248/contrib.entomol.22.7-8.347-405

Lenz F (1924) Eine Konvergenzerscheinung beim Gehausebau der Chironomiden- und Trichopteren-larven. Zoologischer Anzeiger 60: 105-111.

LeSage L, Harrison AD (1980) The biology of Cricotopus (Chironomidae: Orthocladiinae) in an algal-enriched stream. Part I: normal biology. Archiv für Hydrobiologie Supplement 4: 375-418.

Leuchs H, Neumann D (1990) Tube texture, spinning and feeding behaviour of Chironomus larvae. Zoologische Jahrbücher. Abteilung für Systematik, Geographie und Biologie der Tiere 117: 31-40.

Linhart J, Fiurásková M, Uvíra V (2002) Moss- and mineral substrata-dwelling meiobenthos in two different low-order streams. Archiv für Hydrobiologie 154: 543-560. https://doi. org/10.1127/archiv-hydrobiol/154/2002/543

Mackay RJ, Wiggins GB (1979) Ecological diversity in Trichoptera. Annual Review of Entomology 24: 185-208. https://doi.org/10.1146/annurev.en.24.010179.001153

Mackey AP (1976) Quantitative studies on the Chironomidae (Diptera) of the Rivers Thames and Kennet. Archiv für Hydrobiologie 78(2): 240-267.

Madder MCA, Rosenberg DM, Wiens AP (1977) Larval cocoons in Eukiefferiella claripennis (Diptera: Chironomidae). Canadian Entomology 109: 891-892. https://doi.org/10.4039/ Ent109891-6

Malm T, Johanson KR, Wahlberg N (2013) The evolutionary history of Trichoptera (Insecta): A case of successful adaptation to life in freshwater. Systematic Entomology 38(3): 459473. https://doi.org/10.1111/syen.12016

Marziali L, Lenicioni V, Rossaro B (2006) Adaptation of pupae of Chironomidae (Insecta: Diptera) to oxygen-poor habitats. Polish Journal of Ecology 54(4): 687-693.

Marziali L, Rossaro B (2006) Thoracic horn structure in Orthocladiini pupae (Diptera: Chironomidae: Orthocladiinae). Studi trentini di scienze naturali-Acta biologia 82: 69-76. https://www.semanticscholar.org/paper/Thoracic-horn-structure-in-Orthocladiini-pupaeRossaro/733e7edaa03bd6797fbed9401e727c428e67fc84 
Masters BC, Fan V, Ross HA (2011) Species delimitation - a geneious plugin for the exploration of species boundaries. Molecular Ecology Resources 11: 154-157. https://doi. org/10.1111/j.1755-0998.2010.02896.x

McAuliffe J (1984) Competition for space, disturbance, and the structure of a benthic stream community. Ecology 65(3): 894-908. https://doi.org/10.2307/1938063

McGaha YJ (1952) The limnological relations of insects to certain aquatic flowering plants. Transactions of the American Microscopical Society 71(4): 355-381. https://doi. org/10.2307/3223467

McGill BJ, Enquist BJ, Weiher E, Westoby M (2006) Rebuilding community ecology form functional traits. Trends in Ecology and Evolution 21(4): 178-185. https://doi. org/10.1016/j.tree.2006.02.002

McLachlan AJ (1977) Some effects of tube shape on the feeding of Chironomus plumosus L. (Diptera: Chironomidae). Journal of Animal Ecology 46: 139-146. https://doi. org/10.2307/3952

McLachlan AJ, Brennan A, Wotton RS (1978) Particle size and chironomid (Diptera) food in an upland river. Oikos 31(2): 247-252. https://doi.org/10.2307/3543569

McLachlan AJ, Cantrell MA (1976) Sediment development and its influence on the distribution and tube structure of Chironomus plumosus L. (Chironomidae, Diptera) in a new impoundment. Freshwater Biology 6: 437-443. https://doi.org/10.1111/j.1365-2427.1976.tb01632.x

McLachlan AJ, Ladle RJ (2009) The evolutionary ecology of detritus feeding in the larvae of freshwater Diptera. Biological Review 84: 133-141. https://doi.org/10.1111/j.1469185X.2008.00063.x

McWilliam-Hughes SM, Jardine TD, Cunjak RA (2009) Instream C sources for primary consumers in two temperate, oligotrophic rivers: Possible evidence of bryophytes as a food source. Journal of the North American Benthological Society 28: 733-743. https://doi. org/10.1899/08-103.1

Merritt RW, Cummins KW (1996) An introduction to the aquatic insects of North America. Kendall/Hunt Pub. Co., Iowa, 441 pp.

Merz RA (2015) Textures and traction: how tube-dwelling polychaetes get a leg up. Invertebrate Biology 134(1): 61-77. https://doi.org/10.1111/ivb.12079

Milne MJ (1938) Case-building in Trichoptera as an inherited response to oxygen deficiency. The Canadian Entomologist 70(9): 177-180. https://doi.org/10.4039/Ent70177-9

Minter NJ, Buatois LA, Mángano MG (2016) The conceptual and methodological tools of ichnology. In: Mángano MG, Buatois LA (Eds) The trace-fossil record of major evolutionary events. Topics in Geobiology 39, Springer Science+Business Media Dordrecht, Berlin, 1-26. https://doi.org/10.1007/978-94-017-9600-2_1

Moller Pillot HKM (2009) Chironomidae larvae of the Netherlands and adjacent lowlands, Volume 2: Biology and ecology of the Chironomini. KNNV Publishing, Zeist, 270 pp.

Moller Pillot HKM (2013) Chironomidae larvae of the Netherlands and adjacent lowlands, Volume 3: Biology and ecology of the aquatic Orthocladiinae, Prodiamesinae, Buchonomyiinae, Podonominae, Telmatogetoninae. KNNV Publishing, Zeist, 312 pp.

Moog O (1995) Fauna aquatica Austriaca. Katalog zur autökologischen Einstufung aquatischer Organismen Österreichs. Bundesministerium Land- und Forstwirtschaft, Vienna. 
Morse JC, Frandsen PB, Graf W, Thomas JA (2019) Diversity and ecosystem services of Trichoptera. Insects 10(5): 1-27. https://doi.org/10.3390/insects10050125

Moubayed-Breil J, Ashe P (2013) Eukiefferiella brulini sp. n., a commensal species on Ancylus fluviatilis Müller, occurring in the Mediterranean coastal ecosystem of continental France. Ephemera 15(2): 79-92.

Murray D, Ashe P (1985) A description of the adult female of Buchonomyia thienemanni Fittkau and a re-assessment of the phylogenetic position of the subfamily Buchonomyiinae (Diptera, Chironomidae). Spixiana Supplement 11: 149-160.

Namayandeh A, Heard KS, Luiker EA, Culp JM (2016) Chironomidae (Insecta: Diptera) from the eastern Canadian Arctic and subarctic with descriptions of new life stages, a possible new genus, and new geographical records. Journal of Entomological and Acarological Research 48(2): 53-83. https://doi.org/10.4081/jear.2016.5847

Nehring S (1993) Tube-dwelling meiofauna in marine sediments. Internationale Revue der gesamten Hydrobiologie 78(4): 521-534. https://doi.org/10.1002/iroh.19930780411

Nehring S, Jensen P, Lorensen S (1990) Tube-dwelling nematodes: tube construction and possible ecological effects on sediment-water interfaces. Marine Ecology Progress Series 64: 12-128. https://doi.org/10.3354/meps064123

Nilsen HC, Larimore RW (1973) Establishment of invertebrate communities on log substrates in the Laskaskia river, Illinois. Ecology 54(2): 366-374. https://doi.org/10.2307/1934344 Nylander JAA (2004) MrModeltest Version 2. Program Distributed by the Author. Evolutionary Biology Centre, Uppsala University, Uppsala, 2 pp.

Oliver DR (1971) Life history of the Chironomidae. Annual Review of Entomology 16: $211-$ 230. https://doi.org/10.1146/annurev.en.16.010171.001235

Oliver DR, Dillon ME, Cranston PS (1990) A catalog of Nearctic Chironomidae. Research Branch Agriculture Canada Publication 1857/B, Ottawa, 89 pp. http://esc-sec.ca/wp/wpcontent/uploads/2017/03/AAFC_catalog_of_nearctic_chironomidae.pdf

Ólafsson JS (1992) A comparative study on mouthpart morphology of certain larvae of Chironomini (Diptera: Chironomidae) with reference to the larval feeding habits. Journal of Zoology 228: 183-204. https://doi.org/10.1111/j.1469-7998.1992.tb04602.x

Ólafsson JS, Paterson DM (2004) Alteration of biogenic structure and physical properties by tube-building chironomid larvae in cohesive sediments. Aquatic Ecology 38(2): 219-229. https://doi.org/10.1023/B:AECO.0000032050.10546.bb

Patrick R (1966) Catherwood foundation Peruvian-Amazon expedition: Limnological and systematic studies. Monographs of the Academy of Natural Sciences of Philadelphia 14: 338-342.

Patrick R (1996) Rivers of the United States, Volume 3: The Eastern and Southeastern States. John Wiley and Sons, Inc., New York, 829 pp.

Pape T, Blagoderov V, Mostovski MB (2011) Order Diptera Linnaeus, 1758. In: Zhang Z-Q (Ed.) Animal biodiversity: an outline of higher-level classification and survey of taxonomic richness. Zootaxa 3148: 222-229. https://doi.org/10.11646/zootaxa.3148.1.42

Parker BC (2003) A review of research studies at Mountain Lake, Virginia. Banisteria 22: 1-21.

Parker JD, Burkepile DE, Collins DO, Kubanek J, Hay ME (2007) Stream mosses as chemically-defended refugia for freshwater macroinvertebrates. Oikos 116(2): 302-312. https:// doi.org/10.1111/j.0030-1299.2007.15289.x 
Pentecost A (2005) Travertines and their fossils: Archaean to Pliocene. In: Travertine. Springer, Dordrecht, 289-298.

Peterson BJ, Fry B, Deegan L, Hershey A (1993) The trophic significance of epilithic algal production in a fertilized tundra river ecosystem. Limnology and Oceanography 38: 872-878. https://doi.org/10.4319/lo.1993.38.4.0872

Pinder LCV (1986) Biology of freshwater Chironomidae. Annual Review of Entomology 31(1): 1-23. https://doi.org/10.1146/annurev.en.31.010186.000245

Pinder LCV (1995) The habitats of chironomid larvae. In: Armitage PD, Cranston PS, Pinder LCV (Eds) The Chironomidae - biology and ecology of non-biting midges. Springer Netherlands, Netherlands, 107-135. https://doi.org/10.1007/978-94-011-0715-0_6

Prat N, Añón-Suárez D, Rieradevall M (2004) First record of Podonominae larvae living phoretically on the shells of the water snail Chilina dombeyana (Diptera: Chironomidae/Gastropoda: Lymnaeidae). Aquatic Insects 26(3-4): 147-152. https://doi.org/10.1080/0165 0420412331327222

Pringle CM (1985) Effects of chironomid (Insecta; Diptera) tube-building activities on stream diatom communities. Journal of Phycology 21: 185-194. https://doi.org/10.1111/j.00223646.1985.00185.x

Ptatscheck C, Putzki H, Traunspurger W (2017) Impact of deposit-feeding chironomid larvae (Chironomus riparius) on meiofauna and protozoans. Freshwater Science 36(4): 796-804. https://doi.org/10.1086/694461

Reiss F (1984) Neostempellina thienemanni n. gen., n. sp., eine europäische Chironomide mit gehäusetragenden Larven (Diptera, Insecta). Spixiana 7: 203-210. https://www.biodiversitylibrary.org/part/66956\#/summary

Roback SS (1977) First record of a chironomid larva living phoretically on an aquatic hemipteran (Naucoridae). Entomological News 88: 192.

Rodrigo AG, Bertels F, Heled J, Noder R, Shearman H, Tsai P (2008) The perils of plenty: what are we going to do with all these genes? Philosophical Transactions of the Royal Society B 363: 3893-3902. https://doi.org/10.1098/rstb.2008.0173

Rodríguez-Aranda J, Calvo J (1998) Trace fossils and rhizoliths as a tool for sedimentological and palaeoenvironmental analysis of ancient continental evaporite successions. Palaeogeography, Palaeoclimatology, Palaeoecology 140(1-4): 383-399. https://doi.org/10.1016/ S0031-0182(98)00036-4

Rosenberg NA (2007) Statistical tests for taxonomic distinctiveness from observations of monophyly. Evolution 61: 317-323. https://doi.org/10.1111/j.1558-5646.2007.00023.x

Sæther OA (1968) Chironomids of the Finse Area, Norway, with special reference to their distribution in a glacier brook. Archiv für Hydrobiologie 64(4): 426-483.

Sæther OA (1969) Some Nearctic Podonominae, Diamesinae, and Orthocladiinae (Diptera: Chironomidae). Bulletin of the Fisheries Research Board of Canada 170: 1-254.

Sæther OA (1971) Notes on general morphology and terminology of the Chironomidae (Diptera). The Canadian Entomologist 103: 1237-1260. https://doi.org/10.4039/ Ent1031237-9

Sæther OA (1977) Female genitalia in Chironomidae and other Nematocera: morphology, phylogenies, keys. Bulletin of the Fisheries Research Board of Canada 197: 1-204. 
Sæther OA (1980) Glossary of chironomid morphology terminology (Diptera: Chironomidae). Entomologica Scandinavia Supplementum 14: 1-51.

Sæther OA (2000) Phylogeny of the subfamilies of Chironomidae (Diptera). Systematic Entomology 25(3): 393-403. https://doi.org/10.1046/j.1365-3113.2000.00111.x

Sæther OA, Halvorsen GA (1981) Diagnoses of Tvetenia Kieff. emend., Dratnalia n. gen., and Eukiefferiella Thien. emend., with a phylogeny of the Cardiodadius group (Diptera: Chironomidae). Entomologica Scandinavia Supplementum 15: 269-285.

Sandlund OT, Aagaard K (2004) The Atna river: Studies in an Alpine-Boreal watershed, Developments in Hydrobiology, Springer, Dordrecht, 208 pp. https://doi.org/10.1007/978$1-4020-2254-8$

Sanz-Montero ME, Calvo J-P, Angeles García de Cura M, Ornosa C, Outerelo R, RodríguezAranda P (2013) The rise of the diptera-microbial mat interactions during the Cenozoic: consequences for the sedimantary record of saline lakes. Terra Nova 25: 465-471. https:// doi.org/10.1111/ter.12058

Sasa M, Kikuchi M (1995) Chironomidae (Diptera) of Japan. University of Tokyo Press, Tokyo, 333 pp.

Savrda C (2019) Bioerosion of a modern bedrock stream bed by insect larvae (Conecuh River, Alabama): Implications for ichnotaxonomy, continental ichnofacies, and biogeomorphology. Palaeogeography, Palaeoclimatology, Palaeoecology 513: 2-13. https://doi. org/10.1016/j.palaeo.2017.06.030

Schiffels S (2014) Commensal and parasitic Chironomidae. Denisia 163: 393-407. https:// www.zobodat.at/pdf/DENISIA_0033_0393-0407.pdf

Schlee D (1966) Präparation und Ermittlung von Meßwerten an Chironomidae (Diptera). Gewässer und Abwässer 41/42: 169-193.

Scott KMF (1967) The larval and pupal stages of the midge Tanytarsus (Rheotanytarsus) fuscus Freeman. Journal of the Entomological Society of Southern Africa 30: 174-184. https:// hdl.handle.net/10520/AJA00128789_2612

Sehnal F, Sutherland T (2008) Silks produced by insect labial glands. Prion 2(4): 145-153. https://doi.org/10.4161/pri.2.4.7489

Sharp HS (1933) The origin of Mountain Lake, Virginia. The Journal of Geology 41(6): 636641. https://doi.org/10.1086/624075

Simpson KW, Bode RW (1980) Common Larvae of Chironomidae (Diptera) from New York State Streams and Rivers: With Particular Reference to the Fauna of Artificial Substrates. New York State Museum, University of the State of New York, The State Education Department Issues, New York, 105 pp. https://doi.org/10.5962/bhl.title.135538

Soponis AR (1977) A revision of the Nearctic species of Orthocladius (Orthocladius) van der Wulp (Diptera: Chironomidae). The Memoirs of the Entomological Society of Canada 102: 1-187. https://doi.org/10.4039/entm109102fv

Spies M, Andersen T, Epler JH, Watson Jr CN (2009) Chironomidae. In: Brown BV, Borkent A, Cumming JM, Wood DM, Woodley NE, Zumbado M (Eds) Manual of Nearctic Diptera Volume 1. NRC Resrach Press, Ottawa, 437-480.

Steffan AW (1968) Zur Evolution und Bedeutung epizoischer Lebensweise bei ChironomidenLarven (Diptera). Annales Zoologici Fennici 5(1): 144-150. https://www.jstor.org/stable/23731458 
Stief P, Nazarova L, de Beer D (2005) Chimney construction by Chironomus ripariuslarvae in response to hypoxia: microbial implications for freshwater sediments. Journal of the North American Benthological Society 24(4): 858-871. https://doi.org/10.1899/04-137.1

Stream Bryophyte Group (1999) Roles of bryophytes in stream ecosystems. Journal of the North American Benthological Society 18(2): 151-184. https://doi.org/10.2307/1468459

Studler SM (1982) Succession of epiphytic bryophytes Near Mountain Lake, Virginia. The Bryologist 85(1): 51-63. https://doi.org/10.2307/3243140

Stur E, Ekrem T (2011) Exploring unknown life stages of Arctic Tanytarsini (Diptera: Chironomidae) with DNA barcoding. Zootaxa 2743: 27-39. https://doi.org/10.11646/ zootaxa.2743.1.2

Stur E, Martic P, Ekrem T (2005) Non-biting midges as hosts for water mite larvae in spring habitats in Luxembourg. Annales de Limnologie - International Journal of Limnology 41(4): 225-236. https://doi.org/10.1051/limn/2005015

Sublette JE (1970) Type specimens of Chironomidae (Diptera) in the Illinois Natural History Survey Collection, Urbana. Journal of the Kansas Entomological Society 43(1): 44-95. https://www.jstor.org/stable/25083841

Sublette JE, Wirth WW (1980) The Chironomidae and Ceratopogonidae (Diptera) of New Zealand's subantarctic islands. New Zealand Journal of Zoology 7: 299-378. https://doi. org/10.1080/03014223.1980.10423791

Suren A (1993) Bryophytes and associated invertebrates in first-order alpine streams of Arthur's Pass, New Zealand. New Zealand Journal of Marine and Freshwater Research 27(4): 479-494. https://doi.org/10.1080/00288330.1993.9516589

Suren A, Winterbourn M (1991) Consumption of aquatic bryophytes by alpine stream invertebrates in New Zealand. New Zealand Journal of Marine and Freshwater Research 25(3): 331-343. https://doi.org/10.1080/00288330.1991.9516487

Svensson J (1986) Eukiefferiella aneyla sp. n. (Diptera: Chironomidae) a commensalistic midge on Ancylus fluviatilis Muller (Gastropoda: Ancylidae). Entomologica Scandinavia 17: 291298. https://doi.org/10.1163/187631286X00215

Svensson J, Leonardson L (1996) Effects of bioturbation by tube-dwelling chironomid larvae on oxygen uptake and denitrification in eutrophic lake sediments. Freshwater Biology 35(2): 289-300. https://doi.org/10.1046/j.1365-2427.1996.00500.x

Taylor T (1903) Notes on the habits of Chironomus (Orthocladius) sordidellus. Transactions of the Royal Entomological Society of London 51(4): 521-523. https://doi. org/10.1111/j.1365-2311.1903.tb01145.x

Telfer AC, Young MR, Quinn J, Perez K, Sobel CN, Sones JE, Levesque-Beaudin V, Derbyshire R, Fernandez-Triana J, Rougerie R, Thevanayagam A, Boskovic A, Borisenko AV, Cadel A, Brown A, Pages A, Castillo AH, Nicolai A, Glenn Mockford BM, Bukowski B, Wilson B, Trojahn B, Lacroix CA, Brimblecombe C, Hay C, Ho C, Steinke C, Warne CP, Garrido Cortes C, Engelking D, Wright D, Lijtmaer DA, Gascoigne D, Hernandez Martich D, Morningstar D, Neumann D, Steinke D, Marco DeBruin DD, Dobias D, Sears E, Richard E, Damstra E, Zakharov EV, Laberge F, Collins GE, Blagoev GA, Grainge G, Ansell G, Meredith G, Hogg I, McKeown J, Topan J, Bracey J, Guenther J, Sills-Gilligan J, Addesi J, Persi J, Layton KK, D’Souza K, Dorji K, Grundy K, Nghidinwa K, Ronnenberg K, Lee KM, Xie L, Lu L, Penev L, Gonzalez M, Rosati ME, Kekkonen M, Kuzmina M, Iskandar M, Mutanen 
M, Fatahi M, Pentinsaari M, Bauman M, Nikolova N, Ivanova NV, Jones N, Weerasuriya N, Monkhouse N, Lavinia P, Jannetta DP, Hanisch PE, McMullin RT, Ojeda Flores R, Mouttet R, Vender R, Labbee RN, Forsyth R, Lauder R, Dickson R, Kroft R, Miller SE, MacDonald S, Panthi S, Pedersen S, Sobek-Swant S, Naik S, Lipinskaya T, Eagalle T, Decaëns T, Kosuth T, Braukmann T, Woodcock T, Roslin T, Zammit T, Campbell V, Dinca V, Peneva V, Hebert PD, deWaard JR (2015) Biodiversity inventories in high gier: DNA barcoding facilitates a rapid biotic survey of a temperate nature reserve. Biodiversity Data Journal 3: e6313.

Thienemann A (1926) Hydrobiologische Untersuchungen an den kalten Quellen und Bächen der Halbinsel Jasmind auf Rügen. Archiv für Hydrobiologie 17: 221-336 https://doi. org/10.1002/mmnd.48019260102.

Thienemann A (1934) Eine Gesteinsbildende Chironomide. [Lithotanytarsus emaginatus (Goethgebuer)] Zeitschrift für Morphologie und Ökologie der Tiere 28(4): 480-496. https:// doi.org/10.1007/BF00408299

Thienemann A (1936) Chironomiden-Metamorphosen XI. Die Gattung Eukiefferiella. Stettiner Entomologische Zeitung 97: 43-65.

Thienemann A (1954) Chironomus. Leben, Verbreitung und writshaftliche Bedentung der Chironomiden. Die Binnengewässer 20, E. Schweizerbart, Stuttgart, 834 pp.

Tokeshi M (1993) On the evolution of commensalism in the Chironomidae. Freshwater Biology 29: 481-489. https://doi.org/10.1111/j.1365-2427.1993.tb00782.x

Tokeshi M (1995) Species interactions and community structure. In: Armitage PD, Cranston PS, Pinder LCV (Eds) The Chironomidae - biology and ecology of non-biting midges, Springer Netherlands, Netherlands, 297-335. https://doi.org/10.1007/978-94-011-0715-0_12

Tönjes P (1989) Zur Spinnfadenbuildung und zum Wohnröhrenbau bei der Larve von Telmatogeton japonicus, Tokunaga 1933 (Syn. T. remani Remmert 1963) (Chironomidae, Telmatogetoninae). Zoologische Jahrbücher. Abteilung für Anatomie und Ontogenie der Tiere 118: 117-136.

Tonnoir A (1922) Le cycle évoltif de Dactylocladius commensalis sp. nov., Chironomide à larve commensale d'une larve de Blépharocéride. Annales de Biologie Lacustre 11: 279-291.

Vedamanikam VJ, Shazili NAM (2009) The chironomid larval tube, a mechanism to protect the organism from environmental disturbances? Toxicological and Environmental Chemistry 91(1): 171-176. https://doi.org/10.1080/02772240802074934

Voigt S, Hoppe D (2010) Mass occurrence of penetrative trace fossils in Triassic lake deposits (Kyrgyzstan, Central Asia). Ichnos 17(1): 1-11. https://doi.org/10.1080/10420940903358081

Vlčková Š, Linhart J, Uvíra V (2002) Permanent and temporary meiofauna of an aquatic moss Fontinalis antipyretica Hedw. Acta Universitatis Palackianae Olomucensis Facultas Rerum Naturaliuma 39-40: 131-140. https:/www.semanticscholar.org/paper/PERMANENTAND-TEMPORARY-MEIOFAUNA-OF-AN-AQUATIC-V1\%C4\%8Dkov\%C3\%A1Linhart/8dea180e3c006f83eed4168e6523e06d56b3d953

Walde SJ, Davies RW (1984) Invertebrate predation and lotic prey communities: evaluation of in situ enclosure/exclosure experiments. Ecology 65: 1206-1213. https://doi. org/10.2307/1938328

Wallace JB, Merritt RW (1980) Filter-feeding ecology of aquatic insects. Annual Review of Entomology 25: 103-132. https://doi.org/10.1146/annurev.en.25.010180.000535 
Walshe BM (1947) Feeding mechanisms of Chironomus larvae. Nature 160(4066): 474. https:// doi.org/10.1038/160474a0

Walshe BM (1950) The function of haemoglobin in Chironomus plumosus under natural conditions. Journal of Experimental Biology 27: 73-95. https://jeb.biologists.org/content $/ 27 / 1 / 73$

Walshe BM (1951) The feeding habits of certain chironomid larvae (subfamily Tendipedinae). Proceedings of the Zoological Society of London 121(1): 63-79. https://doi. org/10.1111/j.1096-3642.1951.tb00738.x

Weaver JS, Morse JC (1986) Evolution of feeding and case-making behavior in Trichoptera. Journal of the North American Benthological Society 5: 150-158. https://doi. org/10.2307/1467869

Webb CJ, Wilson RS, McGill JD (1981) Ultrastructure of the striated ventromental plates and associated structures of larval Chironominae (Diptera: Chironomidae) and their role in silk-spinning. Journal of Zoology 194: 67-84. https://doi.org/10.1111/j.1469-7998.1981. tb04579.x

Webert KC, Herren CM, Einarsson Á, Bartrons M, Haupteleisch U, Ives AR (2017) Midgestabilized sediment drives the composition of benthic cladoceran communities in Lake Mývatn, Iceland. Ecosphere 8(2): e01659. https://doi.org/10.1002/ecs2.1659

Wiggins GB (2005) Caddisflies: the underwater architects. University of Toronto Press, Toronto, 292 pp. https://doi.org/10.3138/9781442623590

Wiggins GB, Mackay RJ (1978) Some relationships between systematics and trophic ecology in Nearctic aquatic insects, with special reference to Trichoptera. Ecology 59(6): 1211-1220. https://doi.org/10.2307/1938234

Williams DD, Tavares AF, Bryant E (1987) Respiratory device or camouflage? A case for the caddisfly. Oikos 50(1): 42-52. https://doi.org/10.2307/3565400

Winterbourn MJ (2004) Association between a commensal chironomid and its mayfly host in rivers of North Westland. New Zealand Natural Sciences 29: 21-31.

Winterbourn MJ, Rounick JS, Hildrew AG (1986) Patterns of carbon resource utilization by benthic invertebrates in two British river systems: a stable carbon isotope study. Archiv für Hydrobiologie 107: 349-361.

Xue RD, Ali A (1997) Larval case-making behavior of a pestiferous chironomid, Glyptotendipes paripes (Diptera: Chironomidae), with sand grains of sizes. Journal of the American Mosquito Control Association 13: 289-291.

Zavřel J (1939) Chironomidarum Larvae et Nymphae II. (Genus Euhiefferiella Th.). Acta Societatis Scientiarum Naturalium Moravo-Silesiacae 11(10): 1-29. 